OPEN ACCESS

Edited by:

Anne M. Gothmann,

St. Olaf College, United States

Reviewed by:

Ed Hathorne,

GEOMAR Helmholtz Center for Ocean

Research Kiel, Germany

Pierpaolo Zuddas,

Sorbonne Universités, France

*Correspondence:

Sharon Ram

sharon.ram@mail.huji.ac.l

Specialty section:

This article was submitted to

Geochemistry,

a section of the journal

Frontiers in Earth Science

Received: 22 January 2021

Accepted: 19 April 2021

Published: 26 May 2021

Citation:

Ram S and Erez J (2021) The

Distribution Coefficients of Major and

Minor Elements in Coral Skeletons

Under Variable Calcium Seawater

Concentrations.

Front. Earth Sci. 9:657176.

doi: 10.3389/feart.2021.657176

\section{The Distribution Coefficients of} Major and Minor Elements in Coral Skeletons Under Variable Calcium Seawater Concentrations

\section{Sharon Ram* and Jonathan Erez}

The Fredy and Nadine Herrmann Institute of Earth Sciences, The Hebrew University of Jerusalem, Jerusalem, Israel

Coral skeletons are one of the best archives for past ocean seawater (SW) chemistry and isotopes. However, the distribution coefficients of major and minor elements in coral skeletons are not well determined. In this study, we launched an experiment to determine the distribution coefficients of multiple elements in corals' skeletons by changing $\mathrm{Ca}$ concentrations in SW (Casw). Two scleractinian corals, Pocillopora damicornis and Acropora cervicornis were cultured in modified Gulf of Eilat water (Red-Sea) with Casw of approximately 10, 15, 20, and $25 \mathrm{mM}$. After almost three months, the newly grown skeletons were analyzed for the following elements: $\mathrm{Li}, \mathrm{Na}, \mathrm{Mg}, \mathrm{K}, \mathrm{Sr}$, and $\mathrm{Ba}$. Their ratios to $\mathrm{Ca}$ in the coral skeleton $\left(\mathrm{El} / \mathrm{Ca}_{\text {coral }}\right.$ ) increased linearly with $\mathrm{El} / \mathrm{Ca}_{s w}$ (with $R^{2}$ values above 0.98$)$, crossing the origin and thus indicating constant distribution coefficient for each element over the experimental range of El/Casw. The values of $D_{E I}$ were in good agreement with values reported for corals collected in natural seawater. However, differences were observed between the two species, and both were slightly deviating from inorganic aragonite $D$ values. These deviations are well explained by Rayleigh fractionation process in the calcifying fluid (assuming it is mainly seawater). This was observed both for elements with $\mathrm{D}>1$ (Ba and $\mathrm{Sr}$ ) and $\mathrm{D}<1$ ( $\mathrm{Li}, \mathrm{Mg}, \mathrm{Na}$, and K). P. damicornis showed open system behavior ( $20 \%$ of its Ca utilized) while A. cervicornis showed more closed calcifying reservoir ( $~ 50 \%$ of its Ca utilized). The finding that the distribution coefficients of the six minor and trace elements are constant for a given species, should help in the reconstruction of past seawater chemistry based on multielement measurements in fossil corals. In particular, $\mathrm{Na} / \mathrm{Ca}$ coral can be used to reconstruct past ocean $\mathrm{Ca}$ concentrations and with $\mathrm{El} / \mathrm{Ca}_{\text {coral }}$ ratios for other elements, their concentrations for the Cenozoic can be reconstructed.

Keywords: coral calcification, trace elements, distribution coefficient, Rayleigh fractionation, seawater paleochemistry

\section{INTRODUCTION}

The changes in the elemental composition in Scleractinian corals skeletons, provide important archive and proxies for reconstructing ancient seawater (SW) chemistry. It is recognized, that the uptake and partition of elements that coprecipitate with $\mathrm{CaCO}_{3}$ of coral skeleton, changes in response to biotic and abiotic factors e.g., temperature (Beck et al., 1992; Mitsuguchi et al., 1996; 
Cohen et al., 2001; Gaetani and Cohen, 2006; Gaetani et al., 2011), calcification rates (Livingston and Thompson, 1971; Mitsuguchi et al., 2003), and particularly SW chemistry (Goreau, 1959; Swart, 1981; Shen and Boyle, 1987, 1988; Lough and Barnes, 1990; Fallon et al., 2002; Alibert et al., 2003; Giri et al., 2018). Thus coral skeletons provide an important archive on longterm changes in SW chemistry (e.g., Gothmann et al., 2015), together with fluid inclusions in marine evaporites (Hardie, 1996; Horita et al., 2002). The majority of previous coral trace element studies have concentrated on $\mathrm{Sr} / \mathrm{Ca}, \mathrm{Mg} / \mathrm{Ca}$, and $\mathrm{Ba} / \mathrm{Ca}$ that have long residence time (1-10 Ma) and are part of the conservative elements that show a constant ratio in SW. Therefore, changes in their ratios were ascribed mainly to abiotic factors e.g., Sr/Ca and $\mathrm{Mg} / \mathrm{Ca}$ for sea surface temperature (Beck et al., 1992; McCulloch et al., 1994; Cohen et al., 2001; Marshall and McCulloch, 2002; Fallon et al., 2003), Ba/Ca for SW barium, oceanic upwelling and rivers runoff (Lea et al., 1989; Sinclair, 2005; LaVigne et al., 2011, 2016). On longer time scales ( $>10 \mathrm{Ma}$ ) these elemental ratios depend on SW chemistry that has changed over the phanerozoic (Ries, 2004; Gothmann et al., 2015 and references therein). Contrary to $\mathrm{Sr} / \mathrm{Ca}, \mathrm{Mg} / \mathrm{Ca}$, and $\mathrm{Ba} / \mathrm{Ca}$ the ratios of $\mathrm{Li} / \mathrm{Ca}, \mathrm{K} / \mathrm{Ca}$ and $\mathrm{Na} / \mathrm{Ca}$ in coral skeletons received much less attention (Amiel et al., 1973; Mitsuguchi et al., 2010; Mitsuguchi and Kawakami, 2012; Rollion-Bard and Blamart, 2015; Yoshimura et al., 2017; Marchitto et al., 2018) even though they are the major or minor elements in SW and have measurable abundances in the skeletons. Combining both $\mathrm{Li} / \mathrm{Ca}$ and $\mathrm{Mg} / \mathrm{Ca}$ increased the significance of $\mathrm{Mg} / \mathrm{Li}$ as a paleothermometer in corals (Hathorne et al., 2013b; Montagna et al., 2014; D’Olivo et al., 2018; Marchitto et al., 2018; Cuny-Guirriec et al., 2019). Recently a new palaeoceanographic proxy for reconstructing Ca concentration in ancient $\mathrm{SW}$ was introduced based on $\mathrm{Na} / \mathrm{Ca}$ in foraminiferal calcitic shells (Hauzer et al., 2018). It was shown that the partition of $\mathrm{Na}$ into foraminifera shells is primarily related to the SW $\mathrm{Na} / \mathrm{Ca}$ ratio, with no resolvable temperature sensitivity. In view of this novel potential proxy in foraminifera, and the measurements of $\mathrm{Na} / \mathrm{Ca}$ in recent and fossil coral skeletons (e.g., Bar-Matthews et al., 1993; Mitsuguchi et al., 2010; Gothmann et al., 2015; Yoshimura et al., 2017), in the present study, we investigated the effect of elevated $\mathrm{Ca}_{S W}$ concentration on the partition of $\mathrm{Li}, \mathrm{Na}$, $\mathrm{Mg}, \mathrm{K}, \mathrm{Sr}$, and $\mathrm{Ba}$ into the skeletons of the hermatypic corals Pocillopora damicornis and Acropora cervicornis.

\section{MATERIALS AND METHODS}

\section{Laboratory Culturing}

Pocillopora damicornis and Acropora cervicornis mother colonies (raised for 8 years at Red Sea Fish Ltd. aquaculture facility) were cultured in the laboratory for 1 month before the experiment. The corals were held in $500 \mathrm{~L}$ recirculated system, running with filtered ( $1 \mu \mathrm{m}$ polystyrene filter) Gulf of Eilat SW (salinity $40.65 \%$ diluted to a salinity of $35 \%$ ). Once a week, $10 \%$ of the system water was renewed to sustain chemical stability. The system was illuminated by LED lights (Reef Led 90, Red Sea) providing irradiance of $350 \mu \mathrm{mol}$ photons $\mathrm{m}^{-2} \mathrm{~s}^{-1}$ for a light dark cycle of 12:12 h. Two experiments (labeled as exp1 and exp2) were conducted for 80 and 87 days, respectively. Each experiment included four groups, cultured in different calcium concentrations $\left(\mathrm{Ca}_{S W}\right)$ of $\sim 10,15,20$, and $25 \mathrm{mM}$ (Table 1). In the first experiment, each group included five $P$. damicornis fragments $(\sim 1 \mathrm{~cm}$ in length; mean wet weight $187 \pm 11 \mathrm{mg}$ fragment $^{-1}$ ) and five A. cervicornis ( $\sim 1 \mathrm{~cm}$ in length; mean wet weight $205 \pm 12 \mathrm{mg}$ fragment $^{-1}$ ). In the second experiment, each group included ten $P$. damicornis fragments obtained from different mother colony than those of the first experiment $(\sim$ $1 \mathrm{~cm}$ in length; mean wet weight $201 \pm 25 \mathrm{mg}$ fragment $^{-1}$ ) (Table 1). Each fragment, after weighing, was glued with ethyl cyanoacrylate glue (Scotch super glue gel, 3M United States) to the center of a microscope glass slide (Figure 1A). The slides were wet weighed again in order to subtract the cyanoacrylate and primary fragment weight, to assess the new skeleton growth at the end of the experiment. Each group was placed in an individual $75 \mathrm{~L}$ aquarium system, running with modified Gulf of Eilat SW $\left(\mathrm{S}=35 \%\right.$, $\left.\mathrm{Ca}_{S W} \sim 10.3 \mathrm{mM}\right)$. Corals were fed weakly with liquid coral food (Reef Energy, Red Sea) and the water of each aquarium was circulated through a foam fractioner to remove excess DOC and aerate intensively the water. The first group was set as a control, and the $\mathrm{Ca}_{S W}$ level in each experimental group was modified using $\mathrm{CaCl}_{2}$ anhydrous powder (99.99\% trace metal basis, Sigma Aldrich) to a final concentration of approximately 15,20 and $25 \mathrm{mM}$ (Table 1). The carbonate chemistry was not modified, except for the dilution of alkalinity and DIC proportionally to the salinity and exchange with air $\mathrm{CO}_{2}$. During the experiments, the aquaria were tightly covered with transparent plastic foil to minimize evaporation and the salinity was monitored daily with conductivity meter (WTW, multi 3620 IDS, Tetracon 325C conductivity probe, $K=0.475 \mathrm{~cm}^{-1}$ ). The salinity of the aquaria was slightly elevated by the addition of $\mathrm{CaCl}_{2}$ (Table 1). All other experimental conditions were kept approximately the same. $\mathrm{O}_{2}$ and $\mathrm{pH}$ were measured weekly using WTW multi 3620 IDS (WTW optical IDS dissolved oxygen FDO 925; WTW IDS pH- electrodes Sentix 940, calibrated with Radiometer NBS certified buffers and the values are reported using the NBS scale). Note that the system was essentially open to the atmosphere (with aeration) and this kept the $\mathrm{O}_{2}$ and $\mathrm{pH}$ relatively constant (Table 1). Total alkalinity $\left(\mathrm{A}_{T}\right)$ measurements were done weekly using an automatic potentiometric Gran titration beyond the second endpoint (Schneider and Erez, 2006) of roughly $5 \mathrm{~g} \mathrm{SW}$ sample accurately weighed. The acid used was $0.025 \mathrm{M} \mathrm{HCl}$ (ACS reagent 37\%, Sigma Aldrich), and the titrator used was Metrohm 848 Titrino plus (Metrohm, Switzerland) with a precision of $0.008 \mathrm{mmol} / \mathrm{Kg}$. Standard seawater reference solution (Scripps Institution of Oceanography, batch 173) was used to calibrate the $\mathrm{A}_{T}$ measurements. Using CO2SYS (Pierrot et al., 2006) we calculated the relevant carbonate chemistry parameters, including $\Omega_{\text {aragonite }}$ taking into account the Ca concentrations and the salinity changes caused by the addition of anhydrous $\mathrm{CaCl}_{2}$. The data is summarized in the Supplementary Table 1 .

\section{Calcification Rates Measurements}

Once a week, water samples were taken from each aquarium for elemental analysis and alkalinity measurement (in experiment 2 


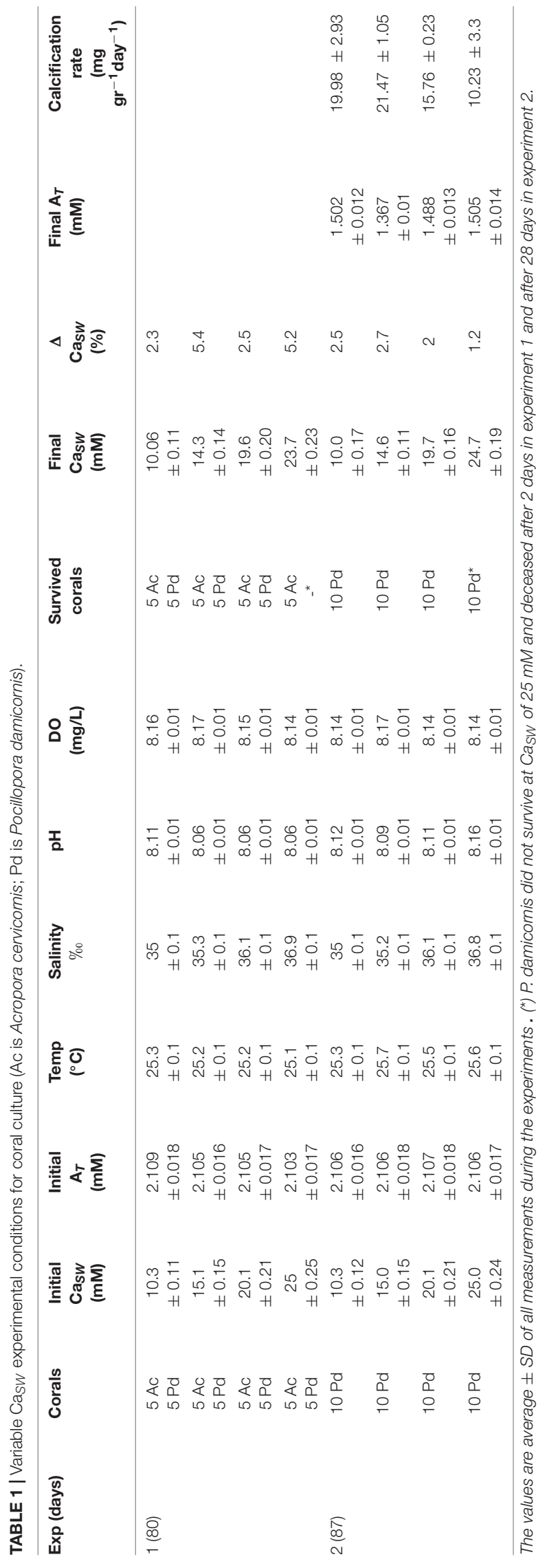

only). Calcification rates were calculated from the difference in $\mathrm{A}_{T}$ measured at the beginning and the end of the experiment. Calcification rates were calculated according to the calcification equation (Schneider and Erez, 2006) and reported in units of $\mu \mathrm{mol} \mathrm{CaCO}_{3} \mathrm{gr}^{-1} \mathrm{day}^{-1}$ :

$$
\begin{aligned}
& \text { Calcification }\left(\mu \mathrm{mol} \mathrm{CaCO} \mathrm{gr}^{-1} \mathrm{day}^{-1}\right) \\
& =\frac{\frac{\Delta A_{T}}{2} \times\left(V_{\text {chamber }}-V_{\text {coral }}\right) \times 1.0264}{T \times C W W}
\end{aligned}
$$

Where $V_{\text {chamber }}(\mathrm{L})$, is the volume of the experimental chamber and $V_{\text {coral }}(\mathrm{L})$ is the displacement volume of the coral, $\mathrm{T}$ is time in days and $\mathrm{C}_{W W}$ is the live coral wet weight (mg). Since culturing aquarium is $\sim 20,000$ times larger than the coral fragments, the fragments volume is negligible.

\section{Sample Preparation}

At the end of the experiment ( 80 and 87 days), the slides were cleaned from any residual algae or bio-film with fine brush, without disturbing the newly grown horizontal section of the skeleton. After cleaning, the slides were wet weighed again and the tissue was removed with an airbrush and collected for further analysis. The slides with the remaining skeletons were treated with $5 \% \mathrm{NaOCl}$ solution (Reagent grade $4.99 \%$, Sigma Aldrich) for $8 \mathrm{~h}$. to remove any residual organic tissue. Thereafter, the slides were thoroughly rinsed with DDW $(18.18 \mathrm{M} \Omega \mathrm{cm})$ and finally moved to sonication bath containing DDW for $5 \mathrm{~min}$. Finally, the slides were left for further $12 \mathrm{~h}$. in DDW to remove residual $\mathrm{SW}$ and $\mathrm{NaOCl}$ solution from its cavities. After drying the slides in the oven $\left(70^{\circ} \mathrm{C}\right.$ for $\left.24 \mathrm{~h}\right)$ the newly grown flat skeleton (Figure 1B) was carefully removed from the glass with a scalpel and spatula under a binocular. Part of the collected skeleton fragments were weighed, crushed and homogenized with a mortar and pestle. Roughly $50 \mathrm{mg}$ of the homogenized skeleton powder (accurately weighed), was then dissolved in $10 \mathrm{ml}$ 5\% $\mathrm{HNO}_{3}$ ( $\geq 99.999$ Trace metal basis, Sigma Aldrich) for elemental analysis.

\section{Elemental Analysis SW and Skeleton}

Trace elements concentrations in the newly grown skeleton and the SW were analyzed by ICP-OES (Spectro Arcos II, Ametek Germany) for major and minor elements ( $\mathrm{Li}, \mathrm{Na}, \mathrm{Mg}, \mathrm{K}, \mathrm{Ca}, \mathrm{Sr}$, and $\mathrm{Ba}$ ). All samples were measured in duplicates without any further dilution using specific methods developed for enriched $\mathrm{Na}$ and enriched $\mathrm{Ca}$ matrixes. SW Elemental concentrations were determined from calibration curves validated by external standards (OSIL IAPSO standard P139, United Kingdom and High Purity Standards SW reference, United States) and by an internal Sc standard, once every 5 samples. Coral skeleton's elemental analysis was determined from calibration curves generated from 5 multi element standard solutions containing $2000 \mathrm{mg} / \mathrm{L} \mathrm{Ca}$ as matrix to match the $\mathrm{CaCO}_{3}$ samples (Custom blends, High Purity Standards, United States). The Standard solutions minor and trace elements ranges included the average concentration of the elements in coral skeletons as described in the literature (Table 2). Complete analytical conditions 

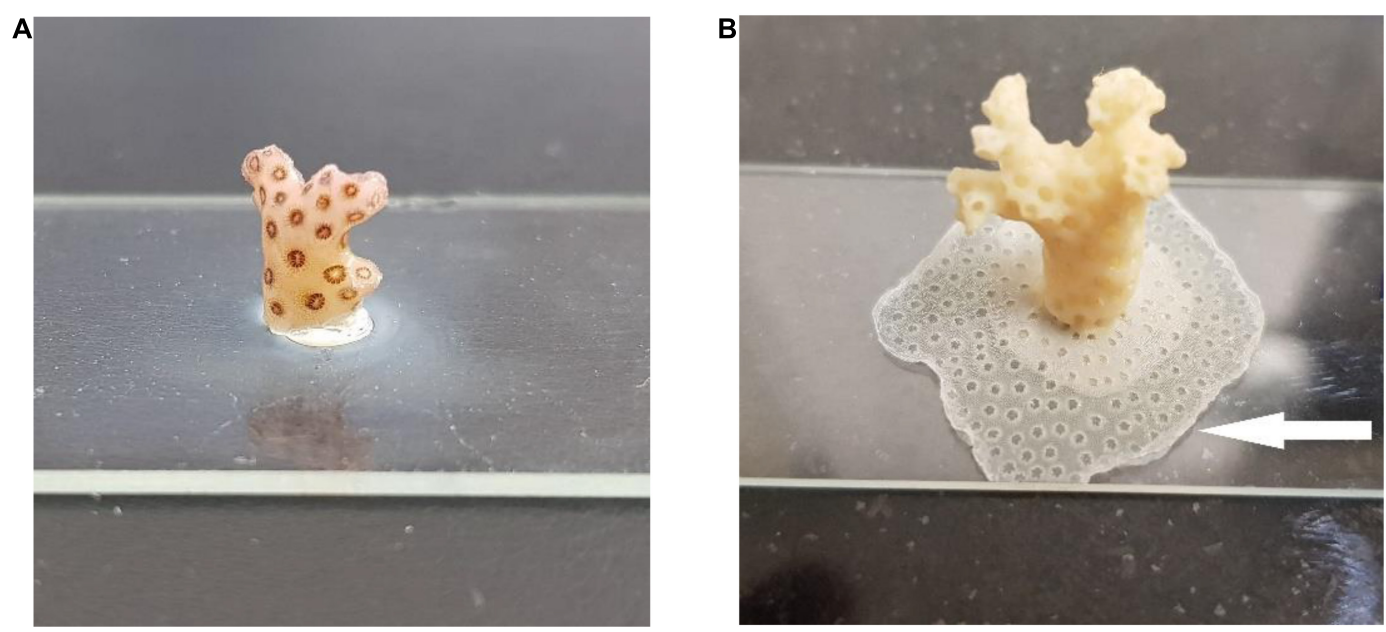

FIGURE 1 | (A) P. damicornis fragment glued to a microscope slide. (B) New skeleton grew horizontally under the experimental conditions (white arrow).

including wavelengths, interferences, standard deviations and errors, as well as ICP-OES parameters are summarized in the Supplementary Table 2. The standard errors of the ratios to $\mathrm{Ca}$ in the SW and corals were $\mathrm{Li} / \mathrm{Ca}=0.927 \%, \mathrm{Na} / \mathrm{Ca}=1.01 \%$, $\mathrm{Mg} / \mathrm{Ca}=1.01 \%, \mathrm{~K} / \mathrm{Ca}=1.03 \%, \mathrm{Sr} / \mathrm{Ca}=0.906 \%, \mathrm{Ba} / \mathrm{Ca}=1.19 \%$ calculated from the duplicates.

\section{Statistical Analysis}

The influence of changing $\mathrm{Ca}_{S w}$ on the partition of elements in the coral skeleton was determined by linear correlation using Pearson correlation coefficients (r). P-Values below 0.05 were considered statistically significant unless otherwise noted. The variance in calcification rates and the variance in $\mathrm{D}_{E l}$ between the two coral species and literature inorganic aragonite were determined by one-way ANOVA (Tukey-Kramer). Statistical analyses were performed using Origin Pro software for Windows (Version 2017, OriginLab, Inc.).

\section{RESULTS}

\section{Calcification Rate}

Total growth and calcification rates were measured only in experiment 2 and were estimated by cumulative alkalinity depletion and by the change in the total coral fragments weight. Both methods were well correlated $\left(R^{2}=0.989 ; p<0.01\right)$ for $P$. damicornis fragments that were grown in $\mathrm{Ca}_{S W}$ of 10.3, 15.0, and 20.1 Mm (Table 1 and Figure 2). Based on the weekly $\mathrm{A}_{T}$ measurements, the corals calcification rates were quite uniform throughout the experiment despite the decrease in $\mathrm{A}_{T}$ (Supplementary Table 1 and Supplementary Figure 1). The average calcification rates were significantly different between the $\mathrm{Ca}$ groups with highest daily $\mathrm{CaCO}_{3}$ addition at $\mathrm{Ca}_{S w}$ of $15.0 \mathrm{mM}\left(21.47 \pm 1.05 \mathrm{mg} \mathrm{gr}^{-1} \mathrm{day}^{-1}\right)$, followed by $10.3 \mathrm{mM}$ $\left(19.98 \pm 2.93 \mathrm{mg} \mathrm{gr}^{-1} \mathrm{day}^{-1}\right), 20.1 \mathrm{mM}(15.76 \pm 0.23 \mathrm{mg}$ $\mathrm{gr}^{-1}$ day $^{-1}$ ) and the lowest $\mathrm{CaCO}_{3}$ addition was observed at $25.0 \mathrm{mM}\left(10.23 \pm 3.3 \mathrm{mg} \mathrm{gr}^{-1} \mathrm{day}^{-1}\right)$ (Figure 2). Further to the low calcification rates, at Casw of $25.0 \mathrm{mM}$ corals fragments did not survive beyond the 28th day into the experiment. Note, however, that alkalinity depletion in this high calcium experiment was 5 times greater than the weight increase caused by inorganic precipitation of $\mathrm{CaCO}_{3}$ in the aquarium. CO2SYS calculations showed that $\Omega_{\text {aragonite }}$ has changed during the experiment as $\mathrm{A}_{T}$ decreased. While this could have affected the values we report, we have no way to separate the effects of $\Omega_{\text {aragonite }}$ on the results using our sampling method. Therefore, our results represent an average of the $\Omega_{\text {aragonite }}$ for the entire experiment.

\section{Skeleton Chemistry and Distribution Coefficients}

Corals skeletal $\mathrm{El} / \mathrm{Ca}\left(\mathrm{El} / \mathrm{Ca}_{\mathrm{Coral}}\right)$ of the cultured groups and the culturing SW El/Ca $\left(\mathrm{El} / \mathrm{Ca}_{S W}\right)$, are presented in Table 2 and Figure 3. The distribution coefficients for these elements $\left(D_{E l}\right)$ are the slopes of the linear regressions in Figure 3. These experimental values are compared to published natural and experimental coral values and to inorganic experimental values, are shown in Table 3. The natural coral $\mathrm{D}_{E l}$ were normalized for $25 \pm 2^{\circ} \mathrm{C}$ as both $\mathrm{Sr}$ and $\mathrm{Mg}$ are influenced by temperature. All conservative elements ( $\mathrm{Li}, \mathrm{Na}, \mathrm{Mg}, \mathrm{K}, \mathrm{Sr}$, and $\mathrm{Ba}$ ) in the coral skeleton $\left(\mathrm{El} / \mathrm{Ca}_{\text {coral }}\right)$ were positively correlated with $\mathrm{Ca}_{S W}$ for both species (Figure 3). The regression curves are linear, cross the origin and are highly significant with $R^{2}$ values of $0.99-0.98$ ( $\rho$ values lower than 0.01 or 0.001 ; Figure 3 ). The distribution coefficients $\left(\mathrm{D}_{E l}\right)$ are therefore constant and equal to the slope of $\mathrm{El} / \mathrm{Ca}_{\text {coral }}$ and $\mathrm{El} / \mathrm{Ca}_{S W}$ line. It is significant that the two separate experiments gave very close values for $P$. damicornis. which could be fitted with one linear equation. For both coral species, the obtained $\mathrm{D}_{E l}$ values for $\mathrm{Li}, \mathrm{Mg}$, $\mathrm{Na}$ and $\mathrm{K}$ were lower than 1 , in the range of $10^{-4}$ to $10^{-3}$, while for $\mathrm{Sr}$ and $\mathrm{Ba}, \mathrm{D}_{E l}$ values were higher than 1 (Table 3). $\mathrm{D}_{E l}$ values between the two species shows significant difference $(\rho>0.05)$ between A. cervicornis and P. damicornis, with higher values for A. cervicornis for most elements excluding $\mathrm{Ba}$ 
TABLE 2 | EI/Ca ratios in SW, new skeleton precipitated under the experimental conditions and the comparison to reported ratios in the literature.

\begin{tabular}{|c|c|c|c|c|c|c|c|c|}
\hline $\mathrm{El} / \mathrm{Ca}$ & Exp & $\mathrm{Ca}_{s w}(\mathrm{mM})$ & sw & A.cervicornis & P.damicornis & $\begin{array}{c}\text { Lit. corals } \\
\left(10.3 \mathrm{mM} 25 \pm 3^{\circ} \mathrm{C}\right)\end{array}$ & $\begin{array}{l}\text { Average lit. } \\
\text { corals }\end{array}$ & References \\
\hline \multirow[t]{8}{*}{$\mathrm{Li} / \mathrm{Ca}$} & 1 & 10.3 & $2.54 \pm 0.02$ & $5.24 \pm 0.17$ & $4.73 \pm 0.2$ & 6.27 (Porites sp.) & $6.38 \pm 1.3$ & Cuny-Guirriec et al., 2019 \\
\hline & & 15.1 & $1.75 \pm 0.02$ & $3.56 \pm 0.2$ & $3.11 \pm 0.2$ & 5.37 (S. siderea) & & Fowell et al., 2016 \\
\hline & & 20.1 & $1.19 \pm 0.03$ & $2.90 \pm 0.19$ & $2.40 \pm 0.2$ & 6.97 (Acro. sp.) & & Montagna et al., 2014 \\
\hline & & 25.0 & $1.03 \pm 0.02$ & $2.10 \pm 0.1$ & & 6.19 (Porites sp.) & & Hathorne et al., 2013a \\
\hline & 2 & 10.3 & $2.48 \pm 0.02$ & & $4.76 \pm 0.1$ & & & \\
\hline & & 15.0 & $1.70 \pm 0.02$ & & $3.26 \pm 0.19$ & & & \\
\hline & & 20.1 & $1.25 \pm 0.01$ & & $2.37 \pm 012$ & & & \\
\hline & & 25.0 & $0.99 \pm 0.01$ & & $1.90 \pm 0.09$ & & & \\
\hline \multirow[t]{8}{*}{$\mathrm{Na} / \mathrm{Ca}$} & 1 & 10.3 & $46.1 \pm 0.8$ & $23.8 \pm 0.88$ & $20.4 \pm 0.75$ & 22.5 (A. digitifera) & $20.80 \pm 1.1$ & Bell et al., 2017 \\
\hline & & 15.1 & $32.3 \pm 0.3$ & $16.2 \pm 0.65$ & $13.5 \pm 0.89$ & 21 (several sp.) & & Yoshimura et al., 2017 \\
\hline & & 20.1 & $23.6 \pm 0.2$ & $12.2 \pm 0.95$ & $8.0 \pm 0.66$ & 19.55 (P. lutea) & & Rollion-Bard and Blamart, 2015 \\
\hline & & 25.0 & $19.5 \pm 0.2$ & $8.4 \pm 0.71$ & & 20 (several sp.) & & Mitsuguchi et al., 2010 \\
\hline & 2 & 10.3 & $46.3 \pm 0.5$ & & $18.8 \pm 0.75$ & & & \\
\hline & & 15.0 & $31.7 \pm 0.3$ & & $12.5 \pm 0.75$ & & & \\
\hline & & 20.1 & $23.5 \pm 0.2$ & & $9.1 \pm 0.63$ & & & \\
\hline & & 25.0 & $18.7 \pm 0.2$ & & $6.1 \pm 0.3$ & & & \\
\hline \multirow[t]{8}{*}{$\mathrm{Mg} / \mathrm{Ca}$} & 1 & 10.3 & $5.36 \pm 0.05$ & $6.88 \pm 0.41$ & $5.14 \pm 0.07$ & 4.9 (P. damicornis) & $4.49 \pm 0.26$ & Giri et al., 2018 \\
\hline & & 15.1 & $3.74 \pm 0.03$ & $4.95 \pm 0.25$ & $3.16 \pm 0.13$ & 4.2 (Porites sp.) & & Hathorne et al., 2013a \\
\hline & & 20.1 & $2.72 \pm 0.02$ & $3.63 \pm 0.21$ & $2.27 \pm 0.18$ & 4.5 (several sp.) & & Mitsuguchi et al., 2010 \\
\hline & & 25.0 & $2.23 \pm 0.03$ & $2.61 \pm 0.18$ & & 4.38 (P. lutea) & & Allison and Finch, 2007 \\
\hline & 2 & 10.3 & $5.3 \pm 0.02$ & & $5 \pm 0.09$ & & & \\
\hline & & 15.0 & $3.63 \pm 0.02$ & & $3.32 \pm 0.12$ & & & \\
\hline & & 20.1 & $2.68 \pm 0.01$ & & $2.12 \pm 0.06$ & & & \\
\hline & & 25.0 & $2.14 \pm 0.01$ & & $1.69 \pm 0.05$ & & & \\
\hline \multirow[t]{8}{*}{$\mathrm{K} / \mathrm{Ca}$} & 1 & 10.3 & $1.03 \pm 0.04$ & $0.21 \pm 0.01$ & $0.18 \pm 0.01$ & 0.171 (Porites sp.) & & Mitsuguchi and Kawakami, 2012 \\
\hline & & 15.1 & $0.72 \pm 0.08$ & $0.13 \pm 0.01$ & $0.12 \pm 0.007$ & & & \\
\hline & & 20.1 & $0.52 \pm 0.13$ & $0.1 \pm 0.005$ & $0.08 \pm 0.005$ & & & \\
\hline & & 25.0 & $0.4 \pm 0.22$ & $0.07 \pm 0.004$ & & & & \\
\hline & 2 & 10.3 & $1.01 \pm 0.05$ & & $0.17 \pm 0.01$ & & & \\
\hline & & 15.0 & $0.69 \pm 0.09$ & & $0.12 \pm 0.01$ & & & \\
\hline & & 20.1 & $0.5 \pm 0.07$ & & $0.08 \pm 0.001$ & & & \\
\hline & & 25.0 & $0.39 \pm 0.08$ & & $0.06 \pm 0.003$ & & & \\
\hline \multirow[t]{8}{*}{$\mathrm{Sr} / \mathrm{Ca}$} & 1 & 10.3 & $8.87 \pm 0.08$ & $9.6 \pm 0.19$ & $9.67 \pm 0.23$ & 9.5 (P. damicornis) & $9.14 \pm 0.26$ & Giri et al., 2018 \\
\hline & & 15.1 & $6.17 \pm 0.05$ & $6.0 \pm 0.22$ & $6.72 \pm 0.37$ & 9.26 (A. digitifera) & & Bell et al., 2017 \\
\hline & & 20.1 & $4.48 \pm 0.04$ & $5.24 \pm 0.31$ & $4.87 \pm 0.17$ & 8.84 (Porites sp.) & & Hathorne et al., 2013a \\
\hline & & 25.0 & $3.7 \pm 0.03$ & $4.15 \pm 0.29$ & & 9 (several sp.) & & Mitsuguchi et al., 2010 \\
\hline & 2 & 10.3 & $8.69 \pm 0.02$ & & $9.59 \pm 0.22$ & & & \\
\hline & & 15.0 & $5.94 \pm 0.02$ & & $6.61 \pm 0.36$ & & & \\
\hline & & 20.1 & $4.38 \pm 0.01$ & & $5.1 \pm 0.21$ & & & \\
\hline & & 25.0 & $3.49 \pm 0.01$ & & $4.37 \pm 0.39$ & & & \\
\hline \multirow[t]{8}{*}{$\mathrm{Ba} / \mathrm{Ca}$} & 1 & 10.3 & $4.83 \pm 0.05$ & $7.59 \pm 0.24$ & $8.43 \pm 0.13$ & 12.4 (F. fargum) & $7.35 \pm 3.1$ & Gonneea et al., 2017 \\
\hline & & 15.1 & $3.37 \pm 0.03$ & $5.07 \pm 0.1$ & $6.2 \pm 0.14$ & 4.72 (P. lobata) & & LaVigne et al., 2016 \\
\hline & & 20.1 & $2.4 \pm 0.03$ & $3.05 \pm 0.09$ & $4.37 \pm 0.08$ & 7.5 (Porites sp.) & & Hathorne et al., 2013b \\
\hline & & 25.0 & $1.97 \pm 0.02$ & $2.64 \pm 0.12$ & & 4.8 (P. lutea) & & Allison and Finch, 2007 \\
\hline & 2 & 10.3 & $4.83 \pm 0.06$ & & $8.68 \pm 0.57$ & & & \\
\hline & & 15.0 & $3.31 \pm 0.03$ & & $5.99 \pm 0.22$ & & & \\
\hline & & 20.1 & $2.44 \pm 0.02$ & & $4.54 \pm 0.18$ & & & \\
\hline & & 25.0 & $1.95 \pm 0.02$ & & $3.85 \pm 0.28$ & & & \\
\hline
\end{tabular}

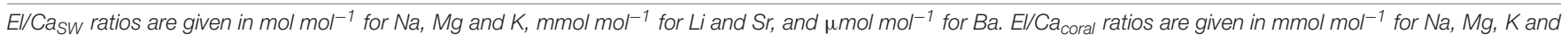
$\mathrm{Sr}$, and $\mu \mathrm{mol} \mathrm{mol}{ }^{-1}$ for Li and Ba.

and Sr (Figure 3). The significant difference between species is seen also for literature values (see values and references in Table 3). Coral $\mathrm{D}_{E l}$ values show similar values for most elements as determined from inorganic experiments, excluding $\mathrm{Li}$ that shows $\mathrm{D}_{\text {inorganic }}>\mathrm{D}_{\text {Coral }}$ and $\mathrm{K}$ that shows $\mathrm{D}_{\text {inorganic }}<\mathrm{D}_{\text {Coral }}$ (Figure 4). These small but significant differences between the inorganic $\mathrm{D}_{E l}$ values and the corals in our and other experiments may well be explained using Rayleigh fractionation model (see discussion).

\section{DISCUSSION}

\section{Casw Influence on Calcification Rates}

A few studies have investigated the effect of Casw on corals calcification rates (Yamazato, 1966; Chalker, 1976; Swart, 1979). They found that calcification rates increased with Casw but Giri et al. (2018) did not observe such effect. This study demonstrates that calcification in $P$. damicornis increased up to $15 \mathrm{mM}$, but further increase to 20.1 and $25 \mathrm{mM}$ decreased the 

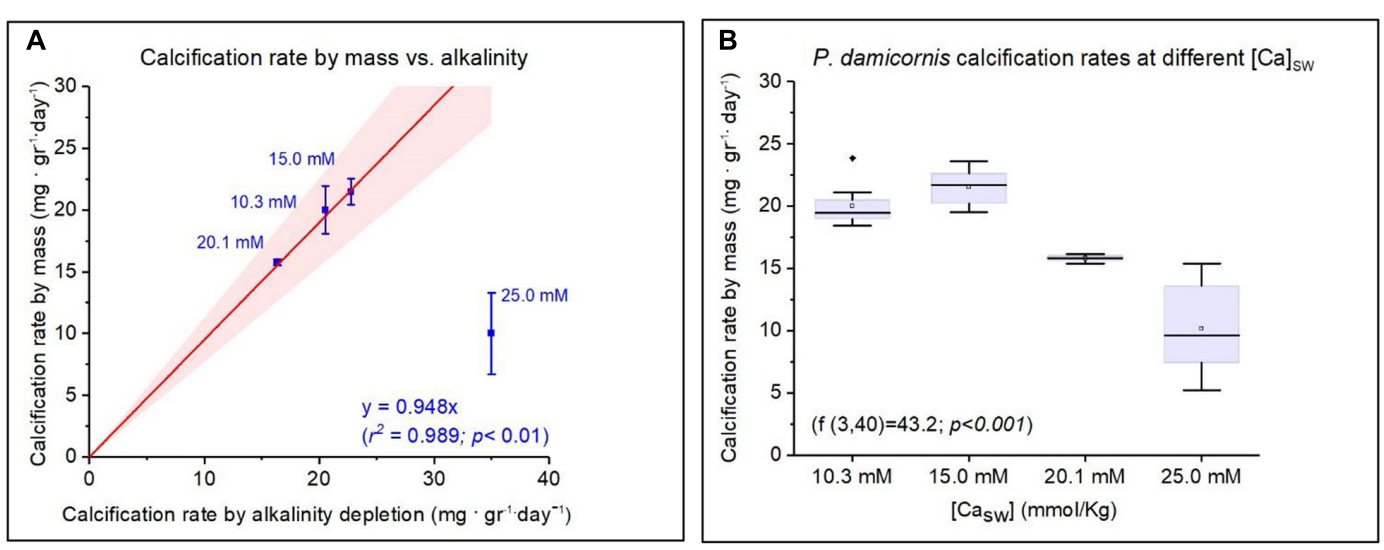

FIGURE 2 | Calcification rates of Pocillopora damicornis under variable Casw. (A) Calcification rate measured by mass addition compared to alkalinity depletion. Corals cultured under Casw of $25 \mathrm{mM}$ are excluded from the regression due to mortality on 28th day. (B) The Mean, median, and deviations of growth rate as a function of Casw with maximum values showed at $15 \mathrm{mM}\left(21.5 \pm 1.05 \mathrm{mg} \cdot \mathrm{gr}^{-1}\right.$. day $\left.{ }^{-1}\right)$.

calcification (Figure 2). Furthermore, it seems that the highest Casw concentration caused severe stress that led to mortality of all corals after 28 days (experiment 2). In experiment 1 all the $P$. damicornis fragments deceased after 2 days in $25 \mathrm{mM}$ Ca but $A$. cervicornis fragments survived at that concentration but the growth rates were not measured and visual observation of the horizontal growth was minimal. The inhibitory effect of high $\mathrm{Ca}_{S W}(>15 \mathrm{mM}$ ) on calcification was documented also for A. cervicornis, A. formosa and A.squamosa (Chalker, 1976; Swart, 1979). Similar observations were made on the foraminifer O. ammonoides (Hauzer et al., 2018). Our experiment suggests that calcification rates do not influence coral $\mathrm{D}_{E l}$ for $\mathrm{Li}, \mathrm{Na}$, $\mathrm{Mg}, \mathrm{K}, \mathrm{Sr}$, and Ba.

\section{The Effect of $\mathrm{El} / \mathrm{Ca}_{\text {sw }}$ on $\mathrm{El} / \mathrm{Ca}_{\text {coral }}$}

It is well documented that alkaline earth metals $(\mathrm{Mg}, \mathrm{Sr}$, and $\mathrm{Ba})$ coprecipitate into corals skeletons as cations substituting for Ca (Livingston and Thompson, 1971; Amiel et al., 1973; Howard and Brown, 1984; Shen and Boyle, 1987, 1988; Sholkovitz and Shen, 1995; McCulloch et al., 2003). Alkali elements (Na, $\mathrm{K}$, and $\mathrm{Li}$ ) in coral skeletons were also measured (Mitsuguchi et al., 2010; Mitsuguchi and Kawakami, 2012; Hathorne et al., 2013a,b; Rollion-Bard and Blamart, 2015; Yoshimura et al., 2017). However, except for the early work of Swart (1979; 1981 for Sr, $\mathrm{Mg}$, and $\mathrm{Na}$ ) and the recent work of Giri et al. (2018 for Sr and $\mathrm{Mg}$ ), we present here the most comprehensive experimental study to determine $\mathrm{D}$ values for $\mathrm{Li}, \mathrm{Na}, \mathrm{Mg}, \mathrm{K}, \mathrm{Sr}$, and $\mathrm{Ba}$ in coral skeleton by changing El/Casw. This experiment was carried out on two species, $P$. damicornis and A. cervicornis, over a large range of $\mathrm{Ca}_{S W}(10.3-25 \mathrm{mM}) . \mathrm{El} / \mathrm{Ca}_{\text {coral }}$ and $\mathrm{El} / \mathrm{Ca}_{S W}$ in the control group $(10.3 \mathrm{mM})$, were similar to those from field collected corals (Table 2) except for $\mathrm{Li} / \mathrm{Ca}_{\text {coral }}$ where our values $\left(\sim 5 \mu \mathrm{mol} \mathrm{mol}{ }^{-1}\right)$ were lower than average field data $\left(6.38 \pm 1.3 \mu \mathrm{mol} \mathrm{mol}^{-1}\right)$. The source of this discrepancy is not clear but part of it may be related to the analytical procedure of the skeleton. It is also possible that this may be temperature related response of the two species used in this experiment
(Montagna et al., 2014; D’Olivo et al., 2018; Cuny-Guirriec et al., 2019). For all elements we observe highly significant positive correlation between $\mathrm{El} / \mathrm{Ca}_{\text {coral }}$ and $\mathrm{El} / \mathrm{Ca}_{S W}$ under increased $\mathrm{Ca}_{S W}$ (Table 2 and Figure 3 ). These results agree with previous study showing such correlations under variable Casw (Giri et al., 2018). The pioneering work of Swart (1981) who cultured four species under four variable $\mathrm{Ca}_{S W}$ and measured $\mathrm{Sr}, \mathrm{Mg}$, and $\mathrm{Na}$ in their skeletons agrees with our results, mainly for $\mathrm{Sr}$ (given the use of EPMA for the skeletal analysis with low sensitivity for concentrations lower than 1\%). In inorganic precipitation experiments for aragonite, the El/Ca ratio increased for the alkali ions $\mathrm{Li}, \mathrm{Na}$, and $\mathrm{K}$, with increasing their concentrations relative to $\mathrm{Ca}$ in the parent solution (Kitano et al., 1975; Okumura and Kitano, 1986). These results agree with our data for both species (Table 2 and Figure 3). However, the actual concentrations in the aragonite were similar to the coral values only for $\mathrm{Na}$ while for $\mathrm{Li}$ the inorganic values were higher, and for $\mathrm{K}$, they were lower. Given that the inorganic experiments were not done in seawater and that kinetic effects are also possible there is a general agreement between the corals and the inorganic experiments.

\section{$\mathrm{D}_{E I}$ Values}

For all the elements measured in this study $(\mathrm{Li}, \mathrm{Na}, \mathrm{Mg}, \mathrm{K}$, $\mathrm{Sr}$, and $\mathrm{Ba}$ ) we observe significant linear regression between $\mathrm{El} / \mathrm{Ca}_{\text {coral }}$ and $\mathrm{El} / \mathrm{Ca}_{\mathrm{SW}}$ going through the origin (Figure 3) suggesting constant distribution coefficients in their aragonitic skeletons. Although $\mathrm{D}_{E l}$ values varied between $P$. damicornis and A. cervicornis, the values are in close proximity to those calculated from field values for various coral species and laboratory inorganic experiments (Figures 3, 4 and Table 3). While $\mathrm{D}_{E l}$ for $\mathrm{Na}, \mathrm{Mg}, \mathrm{Sr}$, and $\mathrm{Ba}$ were consistent with the average $\mathrm{D}_{E l}$ of inorganic aragonite, $\mathrm{D}_{L i}$ for both species were significantly lower than the inorganic ones while $\mathrm{D}_{K}$ was significantly higher. Note, however, that all our experiments were done at constant temperature of $25.4 \pm 0.2^{\circ} \mathrm{C}$ while natural corals are exposed to $\sim 10^{\circ} \mathrm{C}$ variability in their natural environment and $\mathrm{D}_{S r}$ and $\mathrm{D}_{M g}$ are temperature sensitive. For our corals, $\mathrm{D}_{B a}$ was $1.79 \pm 0.02$ 

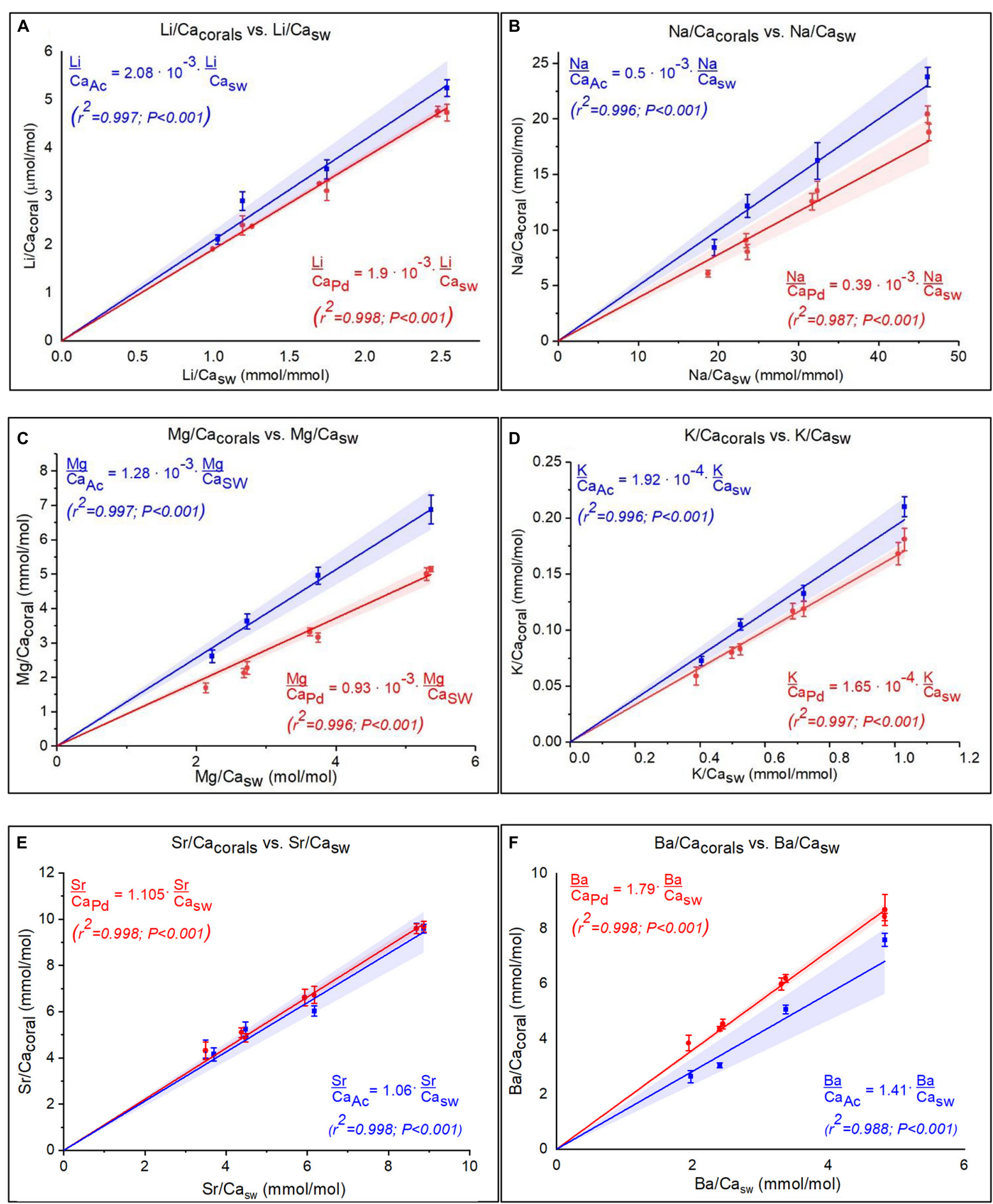

FIGURE 3 | (A-F) El/Ca $a_{\text {coral }}$ as function of El/Casw under variable Casw for both species, for six elements (Pocillopora damicornis in red and Acropora cervicornis in blue). The regressions show linear positive correlations for all elements. Note that for $P$. damicornis data for two separate experiment are shown with slight differences that are within the error on the replicates. The linear regressions that cross the origin imply constant distribtion coefficient for all elements. The shaded area is the $95 \%$ confident bands.

and $1.41 \pm 0.08$ for P. damicornis and A. cervicornis, respectively. $\mathrm{D}_{B a}$ for Favia fargum was determined experimentally by Gonneea et al. (2017) by changing $\mathrm{Ba} / \mathrm{Cas} W$ over a range of 7.3 to 43.9 $\mu$ mole mole $^{-1}$ and temperatures of 22.4 to $27.7^{\circ} \mathrm{C}$. Their average $\mathrm{D}_{B a}$ was $1.75 \pm 0.14$ over all the experimental range (temperature and $\mathrm{Ba} / \mathrm{Ca}$ ) and $1.76 \pm 0.18$ in the temperature experiment at 
TABLE $3 \mid D_{E \mid}$ values for experimental corals compared to various coral species (field collected and experimental normalized to $25 \pm 3^{\circ} \mathrm{C}$ ) and inorganic studies.

\begin{tabular}{|c|c|c|c|c|c|c|c|}
\hline D & A. cervicornis & P. damicornis & Lit. corals & $\begin{array}{l}\text { Average lit. } \\
\text { coral }\end{array}$ & Lit. inorganic & $\begin{array}{l}\text { Average lit. } \\
\text { inorganic }\end{array}$ & References \\
\hline \multirow[t]{4}{*}{$\mathrm{D}_{L i}\left(\times 10^{-3}\right)$} & $2.08 \pm 0.08$ & $1.9 \pm 0.02$ & 2.20 & $2.49 \pm 0.01$ & 3.15 & $3.15+0.06$ & Marriott et al., 2004a,b \\
\hline & & & 2.46 & & & & Cuny-Guirriec et al., 2019 \\
\hline & & & 2.79 & & & & Montagna et al., 2014 \\
\hline & & & 3.00 & & & & Hathorne et al., 2013a \\
\hline \multirow[t]{4}{*}{$\mathrm{D}_{\mathrm{Na}}\left(\times 10^{-3}\right)$} & $0.5 \pm 0.02$ & $0.39 \pm 0.02$ & & & 0.37 & $0.385 \pm 0.001$ & Kitano et al., 1975 \\
\hline & & & 0.45 & & & & Yoshimura et al., 2017 \\
\hline & & & 0.42 & & & & Rollion-Bard and Blamart, 2015 \\
\hline & & & 0.43 & & & & Mitsuguchi et al., 2010 \\
\hline \multirow[t]{2}{*}{$D_{M g}\left(\times 10^{-3}\right)$} & $1.28 \pm 0.03$ & $0.93 \pm 0.02$ & & $0.87 \pm 0.05$ & 0.89 & 0.89 & AlKhatib and Eisenhauer, 2017 \\
\hline & & & 0.95 & & & & Giri et al., 2018 \\
\hline & & & 1.74 & 1.74 & & & Mitsuguchi and Kawakami, 2012 \\
\hline \multirow[t]{6}{*}{$D_{S r}$} & $1.06 \pm 0.03$ & $1.105 \pm 0.01$ & & & 1.11 & $1.13 \pm 0.01$ & AlKhatib and Eisenhauer, 2017 \\
\hline & & & & & 1.13 & & Gaetani and Cohen, 2006 \\
\hline & & & & & 1.15 & & Kinsman and Holland, 1969 \\
\hline & & & 1.01 & $1.01 \pm 0.02$ & & & Giri et al., 2018 \\
\hline & & & 0.99 & & & & Hathorne et al., 2013a \\
\hline & & & 1.01 & & & & Mitsuguchi et al., 2010 \\
\hline \multirow[t]{5}{*}{$D_{B a}$} & $1.41 \pm 0.08$ & $1.79 \pm 0.02$ & & & 1.59 & $1.85 \pm 0.3$ & Dietzel et al., 2004 \\
\hline & & & & & 2.11 & & Gaetani and Cohen, 2006 \\
\hline & & & 1.76 & $1.5 \pm 0.31$ & & & Gonneea et al., 2017 \\
\hline & & & 1.18 & & & & LaVigne et al., 2016 \\
\hline & & & 1.86 & & & & Hathorne et al., 2013a \\
\hline
\end{tabular}

$\mathrm{Ba} / \mathrm{Ca}_{S W}$ closest to our experimental value. Yamazaki et al. (2021) measured $\mathrm{D}_{B a}$ for initial settled polyps of A. gutatus as a function of $\mathrm{Ba}$ concentration and light intensity. Their $\mathrm{D}_{B a}$ values were higher than all previous values ranging from 1.3 to 7.5 with higher values at lower light levels. In the latter paper, however (their Figure 1 and Table 1) the reported $\mathrm{D}_{B a}$ values cannot be considered as distribution coefficients, because the linear plots of $\mathrm{El} / \mathrm{Ca}_{\text {Coral }} \mathrm{vs} \mathrm{El} / \mathrm{Ca}_{S W}$ have significant intercept with the $Y$ axis. Surprisingly, if we combine all the data of this experiment and force the linear regression through the origin, we get a single $\mathrm{D}_{B a}$ value of $1.91 \pm 0.18$ with $R^{2}$ of 0.88 . This value is close to those reported in previous studies (Table 3). The behavior of the distribution coefficient between species relative to the inorganic ones and relative to each other may be well explained using a Rayleigh fractionation model as we show below.

\section{Rayleigh Fractionation}

Several geochemical models have been suggested to explain the elemental and isotopic composition of biogenic skeletal carbonates, based on thermodynamic and kinetic principles. These models in combination with biological calcification mechanisms can eventually be used to explain the chemical and isotopic composition of marine calcifyers in order to use them as environmental proxies (McConnaughey, 1989; Elderfield et al., 1996; Cohen et al., 2001; Gaetani and Cohen, 2006;
Sinclair et al., 2006; Gagnon et al., 2007, 2012). The geochemical and biological models demonstrate that in corals, calcification proceeds from a calcifying fluid within semi-closed privileged space below the calicoblastic epithelium, often defined as the Extra Cellular Fluid (ECF). The major component of this fluid is SW that is supplied to the ECF by either paracellular pathways (Tambutte et al., 2012; Venn et al., 2020) or by another as yet unknown mechanism. Throughout calcification, some elements with $\mathrm{D}_{E l}>1$ (e.g., $\mathrm{Ba}$ and $\mathrm{Sr}$ ) are depleted in the ECF relative to $\mathrm{Ca}$ and these elements may be enriched in the skeleton. Other elements with $\mathrm{D}_{E l}<1$ (e.g., $\mathrm{Mg}, \mathrm{Na}, \mathrm{K}$, and $\mathrm{Li}$ ) are enriched in the ECF while $\mathrm{CaCO}_{3}$ is precipitated because more $\mathrm{Ca}$ is consumed relative to these elements. As a result, the apparent distribution coefficients measured in corals for these elements should be higher than their inorganic ones. This process can be described by a Rayleigh fractionation process, that explains the biogenic distribution coefficients of these elements in coral skeleton. This model was first introduced by Elderfield et al. (1996) to explain the variability of trace elements in foraminifera, and afterward was readily used also for corals (Gaetani and Cohen, 2006; Gagnon et al., 2007; Gaetani et al., 2011; Sinclair, 2015; Giri et al., 2018). The Rayleigh model was widely used to explain Ca and Sr isotopes in corals (Raddatz et al., 2013; Inoue et al., 2015; Gothmann et al., 2016). The use of Rayleigh model to explain the distribution coefficients of all elements in our study 


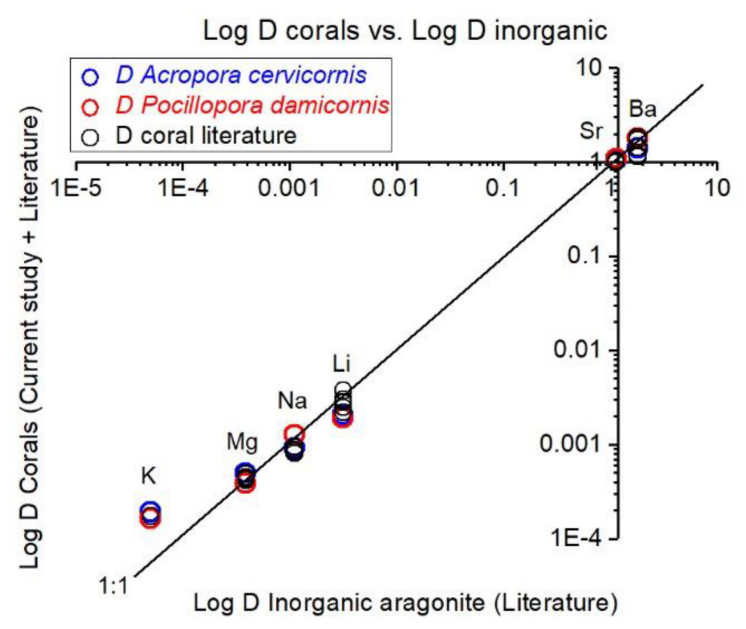

FIGURE 4 | Experimental $D_{E l}$ values and literature values for corals, compared inorganic $D_{E l}$ of aragonite. Our coral $D_{E l}$ values agree well with literature coral values. For $\mathrm{Ba}, \mathrm{Sr}, \mathrm{Mg}$, and $\mathrm{Na}$ the coral values are close to inorganic $\mathrm{D}$ values. For $\mathrm{Li}$, inorganic $\mathrm{D}$ is higher than values in our experiments and for most of field collected corals $\left(25^{\circ} \mathrm{C}\right)$. For $\mathrm{K}$, inorganic $\mathrm{D}$ value is significantly lower than all corals. Suggested explanations for these discrepancies are explained in the section "Discussion."

is very well justified, mainly because we measured experimentally the $\mathrm{D}$ values for two elements with $\mathrm{D}>1$ ( $\mathrm{Ba}$ and $\mathrm{Sr}$ ) and four elements with $\mathrm{D}<1$ ( $\mathrm{Li}, \mathrm{Na}, \mathrm{Mg}$, and $\mathrm{K})$. In Figure 5 we show the expected Rayleigh functions for all six elements based on their inorganic $\mathrm{D}_{E l}$ values (Table 3 ), as a function of $f$ - the fraction of Ca utilized from the closed calcifying reservoir (as fully explained by Elderfield et al., 1996), where:

$$
D_{\text {Coral }}=\left(1-f^{D \text { inorg. }}\right) /(1-f)
$$

Next, we fitted our measured $\mathrm{D}_{\text {Coral }}$ values into Rayleigh fractionation curves for the two species ( $P$. damicornis and A. cervicornis) as shown (Figure 5). Based on this model we conclude that $P$. damicornis behaves as relatively open system with $f$ values between 0.98 and 0.7 and for A. cervicornis $f$ values range between 0.58 and 0.35 i.e., behaving as a half-open system for the various elements (Figure 5). For both species we marked the $f$ ranges in light blue and red shades (Figure 5). As discussed above, $\mathrm{D}_{E l}$ values of corals in experimental studies and many field studies show values that are very similar to our two species (normalized to $25^{\circ} \mathrm{C}$ ). Unfortunately, the inorganic experimental $\mathrm{D}_{E l}$ values show relatively wide range either similar to the corals or larger (e.g., Sr, Mg, Table 3 and Figure 4). For the Rayleigh model we used inorganic average values for $\mathrm{Na}, \mathrm{Sr}$ and $\mathrm{Ba}$ (Table 3) for $\mathrm{Mg}$ we used the values of AlKhatib and Eisenhauer (2017). For two elements (Li and K) the reported inorganic D value fall out or the Rayleigh model shown in Figure 5: For Li the inorganic D value of $3.15 \times 10^{-3}$ (Marriott et al., 2004a,b) is significantly higher than both corals $(2.08 \times$ $10^{-3}$ and $1.9 \times 10^{-3}$ ) and all the field corals (Figures 3, 4). But $\mathrm{D}_{L i}$ of Okumura and Kitano (1986) is $0.27 \times 10^{-3}$ and the average $\mathrm{D}_{L i}$ of both inorganic experiments is $1.7 \times 10^{-3}$, a value that fits well our Rayleigh calculations (see below). Inorganic $\mathrm{D}_{K}$ is $0.5 \times 10^{-4}$ (Okumura and Kitano, 1986) a factor of 3 lower than the coral's values $\left(1.65 \times 10^{-4}, 1.92 \times 10^{-4}\right)$ yielding $f$ values that are close to 1 for both species. We propose two possibilities to resolve the discrepancy in $\mathrm{Li}$ and $\mathrm{K}$ between the reported inorganic values and our Rayleigh model: The first is that $\mathrm{D}$ inorganic values for $\mathrm{Li}$ and $\mathrm{K}$ are inaccurate and should be modified. If we try to fit both species into their Rayleigh Ca utilization ranges, we need to assume $\mathrm{D}_{L i}$ to be $0.16 \times 10^{-3}$ instead of $0.315 \times 10^{-3}$ (Marriott et al., 2004b) i.e., a factor of 2 lower. We note that our $\mathrm{Li} / \mathrm{Ca}_{\text {coral }}$ values $\left(\sim 5 \mu \mathrm{mol} \mathrm{mol}^{-1}\right)$ are lower compared with average literature field corals $(6.38 \mu \mathrm{mol}$ $\mathrm{mol}^{-1}$ ) as we discussed above (Table 3). Even if we take this field corals average it will require a lower inorganic $\mathrm{D}_{L i}(\sim 0.28$ $\times 10^{-3}$ ) to explain the field coral values. For potassium the inorganic $\mathrm{D}_{K}$ value needs to be $1.43 \times 10^{-4}$ instead of $0.5 \times 10^{-4}$ i.e., 3 times higher than reported (Okumura and Kitano, 1986) in order to fit our Rayleigh model (Open markers in Figure 5). A second possibility is that the corals concentrate $\mathrm{K}$ and reduce $\mathrm{Li}$ in the ECF. This explanation opens wide possibilities that cannot be resolved without further experiments dedicated to this specific question. For the present study, we chose the first possibility and suggest that more experimental work is needed to determine accurately $\mathrm{D}_{\mathrm{Li}}$ and $\mathrm{D}_{\mathrm{K}}$ in inorganic experiments. If we use the $\mathrm{D}_{\mathrm{El}}$ values proposed above, we get a good fit to the Rayleigh model for both species (Figure 5) as well as for all the other elements ( $\mathrm{Na}, \mathrm{Mg}, \mathrm{Sr}$, and $\mathrm{Ba}$ ). The use of the Rayleigh model to explain the various $\mathrm{D}_{\mathrm{El}}$ for the two species strongly support the hypothesis that SW is the main source for ions at the ECF (Gaetani and Cohen, 2006; Gagnon et al., 2007; Gothmann et al., 2016; Giri et al., 2018). While these studies do not specifically spell this out, their use of the Rayleigh models, like ours, starts from SW composition at the ECF. Most of the Ca ions needed for calcification is available directly from SW as $\mathrm{Ca}_{S W}=10.3 \mathrm{mM}$, and similarly part of the DIC $\left(\mathrm{DIC}_{S W}=2 \mathrm{mM}\right.$, see discussion on modification of DIC below). Bulk transport of SW is also the source for all the other trace and minor elements found in the skeleton, as can be concluded from their fit to the Rayleigh model. Obviously, the SW in the ECF is replenished once it is depleted of $\mathrm{Ca}$ and $\mathrm{CO}_{3}$ during the calcification process. More evidence for SW at the ECF is discussed in relation to the calcification process is given below.

\section{Implications for Calcification Mechanisms in Corals}

We propose that the fluid in the ECF is essentially SW that arrives to the privileged calcifying space below the calicoblastic epithelium, probably by paracellular pathways (Tambutte et al., 2012). One of the main supports for bulk SW transport to the ECF is coming from observations on Calcein labeling of coral skeletons (Braun and Erez, 2004; Erez and Braun, 2007; Tambutte et al., 2012). Calcein, is a membrane-impermeable fluorescent dye and its presence in large parts of the ECF indicates the presence of SW. The newly precipitated coral aragonite crystals that grow in the flat coral preparation (e.g., Raz-Bahat et al., 2006) are homogeneously labeled with Calcein and provide 


\section{Fitting corals $D_{E l}$ into Rayleigh fractionation model}

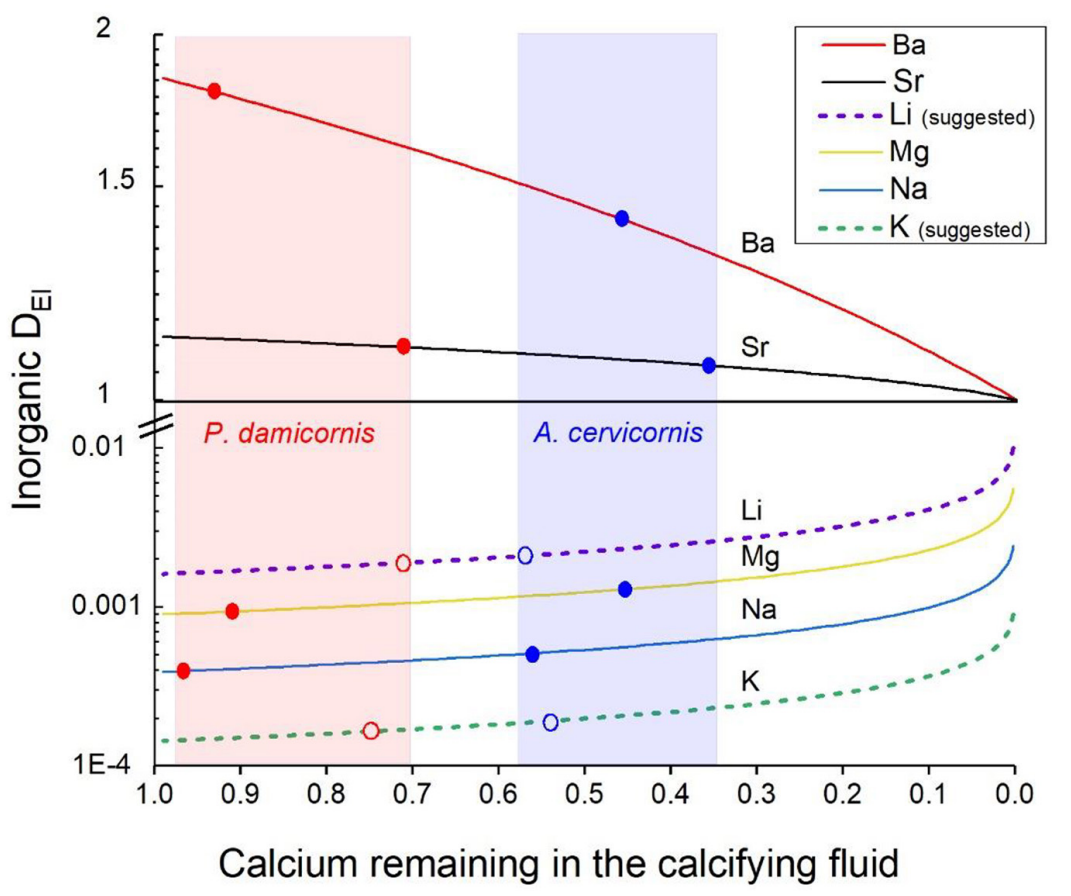

FIGURE 5 | Fitting corals $D_{E I}$ values into a Rayleigh model for the calcifying fluid. Inorganic $D_{E I}$ values for aragonite precipitating from SW are the starting points of the curves on the $Y$ axis. The solid and dotted lines show the evolution of coral $D_{E l}$ precipitating from a closed reservoir (the ECF) for all elements. As Ca is depleted from the ECF elements with $D>1$ decrease relative to Ca while elements with $D<1$ increase their concentration relative to Ca and $D_{E I}$ change accordingly. The Ca depletion is given by the $f$ values ( $f=$ Cainitial /Cafinal). The blue dots are the $D_{E l}$ values for $A$. cervicornis and the red ones for $P$. damicornis. The shaded areas in light blue and red show the range of $f$ values for these corals, respectively. Note that for Li and K we used $D_{E I}$ values marked with open dots as explained in the text.

an evidence that bulk SW is actually the calcifying fluid (e.g., Ohno et al., 2017; Venn et al., 2020). Further support of SW at the ECF is coming from the experiment of Gagnon et al. (2012) that studied the short-term incorporation of isotopes of $\mathrm{Ca}, \mathrm{Sr}, \mathrm{Ba}$, and $\mathrm{Tb}$ into coral skeleton. The measurements using nanoSIMS showed that SW bulk transport is the main source of $\mathrm{Ca}$ (and all the other elements) in the ECF. Other pathways that can bring SW to the ECF such as mega-pinocytosis or SW vacuoles as seen in foraminifera (Bentov et al., 2009), or other leaky pathways are also possible. These may include tissue retraction between polyps as seen at the start of polyp bailout (e.g., Domart-Coulon et al., 2004), or through skeleton exposure due to physical or biological tissue damage (e.g., parrotfish injuries, worms, and mollusks burrowing). There are three major modifications of the SW at the ECF which are: (1) an increase in pH (e.g., Al-Horani et al., 2003; Venn et al., 2011; Gagnon, 2013). (2) Accumulation of DIC as a result of $\mathrm{CO}_{2}$ diffusion and/or bicarbonate transport (e.g., McCulloch et al., 2012, 2017; Sevilgen et al., 2019). (3) Release of organic macromolecules (perhaps including proteins) that serve as an organic matrix which directs the growth patterns, texture, and crystallography of the skeleton (Allemand et al., 1998; Tambutté et al., 2011). Based on our Rayleigh model $P$. damicornis is more open system i.e., it utilized lower fraction of its $\mathrm{Ca}(\sim 20 \%)$ while A. cervicornis behaves as a semi-closed system that utilizes higher fraction of Ca from its ECF $(\sim 50 \%)$. Both strategies may influence the calcification rates: A. cervicornis may invest more energy in elevating the $\mathrm{pH}$ and $\mathrm{DIC}$ and therefore can utilize higher fraction of the SW Ca (Figure 5). P. damicornis on the other hand, exchanges its SW at the ECF faster and its $\mathrm{pH}$ and DIC elevations may therefore be lower. This may explain the difference in their calcification rates suggesting that the closed system strategy of A. cervicornis is more efficient. Based on the growth of $P$. damicornis in the second experiment, and the total growth in the first experiment we can estimate that $A$. cervicornis grew at least twice faster than $P$. damicornis (see Supplementary Table 3).

Independent evidence for our Rayleigh calcification model comes from $\mathrm{B} / \mathrm{Ca}$ and $\delta^{11} \mathrm{~B}$ in laboratory and field studies. $\delta^{11} \mathrm{~B}$ is used to calculate the $\mathrm{pH}$ and $\mathrm{B} / \mathrm{Ca}$ to calculate the $\mathrm{CO}_{3}$ concentration at the ECF. These two parameters of the carbonate system allow calculation of the DIC in the calcifying fluid (Allison et al., 2014; DeCarlo et al., 2017, 2018). In addition, DeCarlo et al. (2017) suggested that Raman spectra of the skeleton correlate well with $\Omega_{\text {aragonite }}$ and this allows to calculate the Ca at the ECF. Similar approach was used by Ross et al. (2019) where the authors compared skeleton derived chemistry at the ECF for different species collected in several locations in Australia. In both studies, the data on Acropora species and $P$. damicornis, support our results i.e., Acropora calcifies faster than P. damicornis. Furthermore, their estimated DIC and $\Omega_{\text {aragonite }}$ yielded higher 
values for Acropora compared to Pocillopora which may explain Acropora's faster calcification rate. In both papers mentioned above, the Ca estimates at the ECF for the Acropora species is lower than those of $P$. damicornis in agreement with our $f$ values suggesting higher Ca utilization for Acropora. The geochemical ECF estimates represent longer time averages (days, weeks or months) and may show steady state chemical compositions of the ECF. There is good agreement of these values with the previous short-term microelectrode and fluorescent dyes experiments, that represent short term values of $\mathrm{pH}, \mathrm{DIC}$, and $\mathrm{Ca}$ (e.g., Al-Horani et al., 2003; Venn et al., 2011; Sevilgen et al., 2019 and references therein). Both types of studies support each other, and biological direct observation increase the confidence of the calcification mechanisms that are proposed based on geochemical data. The most significant process in the calcification mechanism is that the ECF is essentially seawater that is modified by the coral mainly to increase its $\mathrm{pH}, \mathrm{DIC}$, and $\Omega_{\text {aragonite }}$. High $\Omega_{\text {aragonite }}$ values are needed to start precipitation of the skeleton, but during the precipitation process $\mathrm{Ca}, \mathrm{CO}_{3}, \mathrm{DIC}$, and $\mathrm{pH}$ are all decreasing until calcification stops. The dynamics of these processes may be controlled by the diurnal cycle as light enhanced calcification is well documented in hermatypic corals (e.g., Cohen et al., 2016 and references therein).

\section{Implications for Paleoceanographic Reconstructions}

Corals are successfully applied as paleoceanography recorders mainly for paleotemperature based on $\delta^{18} \mathrm{O}, \mathrm{Sr} / \mathrm{Ca}$, and $\mathrm{Mg} / \mathrm{Ca}$ (e.g., Smith et al., 1979; Beck et al., 1992; Mitsuguchi et al., 1996; Felis et al., 2004; D'Olivo et al., 2018 and references therein). Reconstructions of ocean chemistry based on corals is scarce (Bender, 1973; Ries et al., 2006), but recently, the study of Gothmann et al. (2015), showed the high potential for such reconstructions over the past 200 Ma. Our findings strengthen the confidence of these paleo-studies have important implications for past ocean chemistry reconstruction. One of the main hurdles of proxies used in coral was the "vital effects" i.e., the deviation of coral skeletons from expected thermodynamic values of aragonite precipitation from seawater (e.g., McConnaughey, 1989; Adkins et al., 2003; Gagnon et al., 2007; Gothmann et al., 2016). In this study we show that seawater is the initial calcifying fluid at the ECF and fractionation of trace elements in the skeleton is constant for each species following a Rayleigh process from a semi-closed ECF reservoir. $\mathrm{D}_{\text {coral }}$ values are therefore constant (i.e., intercept 0 in the El/Ca plots) for each of the two species we studied (Figure 3). We propose that the closure of the ECF is mainly in order to modify its carbonate chemistry i.e., elevation of $\mathrm{pH}, \mathrm{DIC}$ and $\Omega_{\text {aragonite }}$ and this closure is the main cause for Rayleigh process that we observe in coral skeletons trace elements.

Reconstruction of past seawater chemistry based on coral skeletons may be more reliable by measuring elements with $\mathrm{D}>1(\mathrm{Ba}$ and $\mathrm{Sr})$ and $\mathrm{D}<1(\mathrm{Na}$ and $\mathrm{Mg})$ and compare it to inorganic values. This may help to remove the vital effects related to the Rayleigh process. The most important ratio in these reconstructions is $\mathrm{Na} / \mathrm{Ca}_{\text {skeleton }}$ as proposed by Hauzer et al. (2018) and Houedec et al. (2021) for foraminifera during the Cenozoic. This follows from the assumption that $\mathrm{Na}$ concentration is constant over the last 50-100 Ma and Casw may be calculated from $\mathrm{Na} / \mathrm{Ca}_{\text {coral }}$. $\mathrm{Na}$ concentration in coral skeletons is relatively high (e.g., Mitsuguchi et al., 2010; the present study) and since Kawabata et al. (2021), suggested that $\mathrm{Na}$ substitutes $\mathrm{Ca}$ in the lattice of aragonite based on K-edge $\mathrm{X}$-ray absorption near edge structure (XANES) measurements, the $\mathrm{Na} / \mathrm{Ca}_{\text {coral }}$ may indeed be used as a proxy for Casw. Once we know the past $\mathrm{Ca}$, with information on temperature, it is also possible to calculate $\mathrm{Sr}, \mathrm{Mg}, \mathrm{K}, \mathrm{Li}$, and other elements that have shorter residence times $(\mathrm{Mg} \sim 14 \mathrm{Ma} ; \mathrm{K} \sim 7 \mathrm{Ma}$; $\mathrm{Sr} \sim 6 \mathrm{Ma}$; $\mathrm{Li}$ and $\mathrm{Ca} \sim 1 \mathrm{Ma}$; Pilson, 2013). Thus, despite the complex biological processes involved in the calcification of corals, their skeletons provide a unique and reliable archive for paleoceanoraphic reconstructions.

\section{SUMMARY}

In this study two scleractinian corals species, Pocillopora damicornis and Acropora cervicornis were cultured under variable seawater calcium $\left(\mathrm{Ca}_{S w}\right)$ ranging from $\sim 10$ to $25 \mathrm{mM}$. The results demonstrate that the incorporation of the conservative elements $\mathrm{Li}, \mathrm{Na}, \mathrm{Mg}, \mathrm{K}, \mathrm{Sr}$ and $\mathrm{Ba}$ into the coral's skeletons, is directly related to the $\mathrm{El} / \mathrm{Ca}_{S W}$ ratio. The significant linear regression between $\mathrm{El} / \mathrm{Ca}_{\text {coral }}$ and $\mathrm{El} / \mathrm{Ca}_{S W}$, going through the origin, suggests constant distribution coefficients $\left(\mathrm{D}_{\text {coral }}\right)$ for each element. For both coral species, $\mathrm{D}_{E l}$ values for $\mathrm{Na}, \mathrm{Mg}, \mathrm{Sr}$, and $\mathrm{Ba}$ were in close proximity to the inorganic $\mathrm{D}_{E l}$ values, however, $\mathrm{D}_{L i}$ were slightly lower and $\mathrm{D}_{K}$ higher than the inorganic values. Rayleigh fractionation model explains well the variation in $\mathrm{D}_{E l}$ between the two species and the inorganic $\mathrm{D}_{E l}$ yielding the following conclusions:

SW is the main source for ions at the ECF, which shows precipitation from a semiclosed reservoir, that can be modeled using Rayleigh fractionation process.

Different coral species demonstrate different strategies with respect to their $\mathrm{Ca}$ utilization from the ECF. $P$. damicornis behaves like relatively open system while A. cervicornis is a halfopen system, that may be more efficient as it shows higher calcification rate.

For $\mathrm{Li}$ and $\mathrm{K}$ the published inorganic $\mathrm{D}_{E l}$ values are inconsistent with the Rayleigh model based on the coral $\mathrm{D}_{E l}$. We propose that $\mathrm{D}_{L i}$ and $\mathrm{D}_{K}$ may be inaccurate and suggest hypothesized alternative values, however, this needs direct experimental study.

Finally, this study shows that coral skeletal trace elements may serve as highly reliable archive for paleoceanographic reconstructions. $\mathrm{Na} / \mathrm{Ca}_{\text {coral }}$ may be used to calculate past $\mathrm{Ca}_{S W}$ for the Cenozoic (as $\mathrm{Na}_{S W}$ was probably constant). Other elemental concentrations may thus be calculated based on their skeletal values and $D_{E l}$ values of this paper.

\section{DATA AVAILABILITY STATEMENT}

The original contributions presented in the study are included in the article/Supplementary Material, further inquiries can be directed to the corresponding author. 


\section{AUTHOR CONTRIBUTIONS}

JE designed and directed the study, and edited the manuscript. SR performed the growth experiments, ICP-OES analyses, processing and analyzing the data, and wrote the manuscript. Both authors contributed to the article and approved the submitted version.

\section{FUNDING}

This study was funded by Israel Science Foundation \# 790/16 to JE.

\section{REFERENCES}

Adkins, J. F., Boyle, E. A., Curry, W. B., and Lutringer, A. (2003). Stable isotopes in deep-sea corals and a new mechanism for "vital effects". Geochimica et Cosmochimica Acta 67, 1129-1143. doi: 10.1016/S0016-7037(02)01203-6

Al-Horani, F. A., Al-Moghrabi, S. M., and De Beer, D. (2003). The Mechanism of Calcification and Its Relation to Photosynthesis and Respiration in the Scleractinian Coral Galaxea fascicularis. Marine Biology 142, 419-426. doi: 10. 1007/s00227-002-0981-8

Alibert, C., Kinsley, 1, Fallon, S. J., McCulloch, M. T., Berkelmans, R., and McAllister, F. (2003). Source of Trace Element Variability in Great Barrier Reef Corals Affected by the Burdekin Flood Plumes. Geochimica et Cosmochimica Acta 67, 231-246. doi: 10.1016/S0016-7037(02)01055-4

AlKhatib, M., and Eisenhauer, A. (2017). Calcium and Strontium Isotope Fractionation during Precipitation from Aqueous Solutions as a Function of Temperature and Reaction Rate. II. Aragonite. Geochimica et Cosmochimica Acta 209, 320-342. doi: 10.1016/j.gca.2017.04.012

Allemand, D., Tambutte, E., Girard, J. P., and Jaubert, J. (1998). Organic Matrix Synthesis in the Scleractinian Coral Stylophora Pistillata: Role in Biomineralization and Potential Target of the Organotin Tributyltin. The Journal of Experimental Biology 201, 2001-2009. doi: 10.1007/s13398-0140173-7.2

Allison, N., and Finch, A. A. (2007). High Temporal Resolution $\mathrm{Mg} / \mathrm{Ca}$ and Ba/Ca Records in Modern Porites Lobata Corals. Geochemistry, Geophysics Geosystems 8, 1477. doi: 10.1029/2006GC001477

Allison, N., Cohen, I., Finch, A. A., Erez, J., and Tudhope, A. W. (2014). Corals concentrate dissolved inorganic carbon to facilitate calcification. Nature Communications 5, 5741.

Amiel, A. J., Miller, D. S., and Fridman, G. M. (1973). Distribution and Nature of Incorporation of Trace Elements in Modern Aragonitic Corals. Sedimentology 20, 47-64. doi: 10.1111/j.1365-3091.1973.tb01606.x

Bar-Matthews, M., Wasserburg, G. J., and Chen, J. H. (1993). Diagenesis of fossil coral skeletons: Correlation between trace elements, textures, and $234 \mathrm{U} / 238 \mathrm{U}$. Geochim. Cosmochim. Acta 57, 257.

Beck, J. W., Edwards, R. L., Ito, E., Taylor, F. W., Recy, J., Rougerie, F., et al. (1992). Sea-Surface Temperature from Coral Skeletal Strontium/Calcium Ratios. Science 257, 644-647. doi: 10.1126/science.257.5070.644

Bell, T., Nishida, K., Ishikawa, K., Suzuki, A., Nakamura, T., Sakai, K., et al. (2017). Temperature-Controlled Culture Experiments with Primary Polyps of Coral Acropora Digitifera: Calcification Rate Variations and Skeletal Sr/Ca, $\mathrm{Mg} / \mathrm{Ca}$, and Na/Ca Ratios. Palaeogeography, Palaeoclimatology, Palaeoecology 484, 129-135. doi: 10.1016/j.palaeo.2017.03.016

Bender, M. L. (1973). Helium-uranium dating of corals. Gear chitn Cosmochim. Acta 37, 1229-1247.

Bentov, S., Brownlee, C., and Erez, J. (2009). The role of seawater endocytosis in the biomineralization process in calcareous foraminifera. Proc. Natl. Acad. Sci. U.S.A. 106, 21500-21504. doi: 10.1073/pnas.0906636106

Braun, A., and Erez, J. (2004). Preliminary observations on sea water utilization during calcification in scleractinian corals. Eos. Trans. AGU 85, 14B-14B.

\section{ACKNOWLEDGMENTS}

We thank Yair Rosenthal and David Evans for initiating the idea that $\mathrm{Na}$ in biogenic carbonates may serve as a proxy for past SW calcium. We also thank Yigal Erel for reviewing this manuscript, Adam Levi, Hagar Hauzer, and Itzhak Geva for lab assistance, and the two reviewers for improving the manuscript.

\section{SUPPLEMENTARY MATERIAL}

The Supplementary Material for this article can be found online at: https://www.frontiersin.org/articles/10.3389/feart. 2021.657176/full\#supplementary-material

Chalker, B. E. (1976). Calcium Transport during Skeletogenesis in Hermatypic Corals. Comparative Biochemistry and Physiology - Part A: Physiology 54, 455-459. doi: 10.1016/0300-9629(76)90049-9

Cohen, A. L., Layne, G. D., Hart, S., and Lobel, P. S. (2001). Implications for the Paleotemperature Proxy A. Paleoceanography 16, 20-26.

Cohen, I., Dubinsky, Z., and Erez, J. (2016). Light Enhanced Calcification in Hermatypic Corals: New Insights from Light Spectral Responses. Frontiers in Marine Science 2:122. doi: 10.3389/fmars.2015.00122

Cuny-Guirriec, K., Douville, E., Reynaud, S., Allemand, D., Bordier, L., Canesi, M., et al. (2019). Coral Li/Mg Thermometry: Caveats and Constraints. Chemical Geology 523, 162-178. doi: 10.1016/j.chemgeo.2019.03.038

D’Olivo, J. P., Sinclair, D. J., Rankenburg, K., and McCulloch, M. T. (2018). A Universal Multi-Trace Element Calibration for Reconstructing Sea Surface Temperatures from Long-Lived Porites Corals: Removing 'Vital-Effects.'. Geochimica et Cosmochimica Acta 239, 109-135. doi: 10.1016/j.gca.2018.07.035

DeCarlo, T. M., Comeau, S., Cornwall, C. E., and Mcculloch, M. T. (2018). Coral resistance to ocean acidification linked to increased calcium at the site of calcification. Proc. R. Soc. B 285, 20180564. doi: 10.1098/rspb.2018.0564

DeCarlo, T. M., D’Olivo, J. P., Foster, T., Holcomb, M., Becker, T., and McCulloch, M. T. (2017). Coral calcifying fluid aragonite saturation states derived from Raman spectroscopy. Biogeosciences 14, 5253-5269. doi: 10.5194/bg-14-52532017

Dietzel, M., Gussone, N., and Eisenhauer, A. (2004). Co-Precipitation of $\mathrm{Sr}^{2+}$ and $\mathrm{Ba}^{2+}$ with Aragonite by Membrane Diffusion of $\mathrm{CO}_{2}$ between 10 and $50 \mathrm{j} \mathrm{C}$. Chemical Geology 203, 139-151. doi: 10.1016/j.chemgeo.2003.09.008

Domart-Coulon, I., Tambutté, S., Tambutté, E., and Allemand, D. (2004). Short term viability of soft tissue detached from the skeleton of reef-building corals. J. Exp. Mar. Biol. Ecol. 309, 199-217.

Elderfield, H., Bertram, C. J., and Erez, J. (1996). A Biomineralization Model for the Incorporation of Trace Elements into Foraminiferal Calcium Carbonate. Earth and Planetary Science Letters. 142, 409-423.

Erez, J., and Braun, A. (2007). Calcification in hermatypic corals is based on direct seawater supply to the biomineralisation site. Geochim. Cosmochim. Acta 71, SA260.

Fallon, S. J., McCulloch, M. T., and Alibert, C. (2003). Examining Water Temperature Proxies in Porites Corals from the Great Barrier Reef: A Cross-Shelf Comparison. Coral Reefs 22, 389-404. doi: 10.1007/s00338-003-0 322-5

Fallon, S. J., White, J. C., and McCulloch, M. T. (2002). Porites Corals as Recorders of Mining and Environmental Impacts: Misima Island, Papua New Guinea. Geochimica et Cosmochimica Acta 66, 45-62.

Felis, T., Lohmann, G., and Kuhnert, H. (2004). Increased seasonality in Middle East temperatures during the last interglacial period. Nature 429, 164-168. doi: 10.1038/nature02546

Fowell, S. E., Sandford, K., Stewart, J. A., Castillo, K. D., Ries, J. B., and Foster, G. L. (2016). Intrareef variations in $\mathrm{Li} / \mathrm{Mg}$ and $\mathrm{Sr} / \mathrm{Ca}$ sea surface temperature proxies in the Caribbean reef-building coral Siderastrea siderea. Paleoceanography 31, 1315-1329. 
Gaetani, G. A., and Cohen, A. L. (2006). Element Partitioning during Precipitation of Aragonite from SW: A Framework for Understanding Paleoproxies. Geochimica et Cosmochimica Acta 70, 4617-4634. doi: 10.1016/j.gca.2006.07. 008

Gaetani, G. A., Cohen, A. L., Zhengrong, W., and Crusius, J. (2011). RayleighBased, Multi-Element Coral Thermometry: A Biomineralization Approach to Developing Climate Proxies. Geochimica et Cosmochimica Acta 75, 1920-1932. doi: 10.1016/j.gca.2011.01.010

Gagnon, A. C. (2013). Coral Calcification Feels the Acid. PNAS 110, 1567-1568. doi: 10.1073/pnas. 1221308110

Gagnon, A. C., Adkins, J. F., and Erez, J. (2012). Seawater Transport during Coral Biomineralization. Earth and Planetary Science Letters 329-330, 150-161. doi: 10.1016/j.epsl.2012.03.005

Gagnon, A. C., Adkins, J. F., Fernandez, D. P., and Robinson, L. F. (2007). Sr/Ca and $\mathrm{Mg} / \mathrm{Ca}$ Vital Effects Correlated with Skeletal Architecture in a Scleractinian Deep-Sea Coral and the Role of Rayleigh Fractionation. Earth and Planetary Science Letters 261, 280-295. doi: 10.1016/j.epsl.2007.07.013

Giri, S. J., Swart, P. K., and Devlin, Q. B. (2018). The Effect of Changing SW Ca and $\mathrm{Mg}$ Concentrations upon the Distribution Coefficients of $\mathrm{Mg}$ and $\mathrm{Sr}$ in the Skeletons of the Scleractinian Coral Pocillopora Damicornis. Geochimica et Cosmochimica Acta 222, 535-549. doi: 10.1016/j.gca.2017.11.011

Gonneea, M. E., Cohen, A. L., DeCarlo, T. M., and Charette, M. A. (2017). Relationship between Water and Aragonite Barium Concentrations in Aquaria Reared Juvenile Corals. Geochimica et Cosmochimica Acta 209, 123-134. doi: 10.1016/j.gca.2017.04.006

Goreau, T. F. (1959). The Physiology of Skeleton Formation in Corals. I. a Method for Measuring the Rate of Calcium Deposition By Corals Under Different Conditions. The Biological Bulletin 116, 59-75. doi: 10.2307/1539156

Gothmann, A. M., Bender, M. L., Blättler, C. L., Swart, P. K., Giri, S. J., Adkins, J. F., et al. (2016). Calcium Isotopes in Scleractinian Fossil Corals since the Mesozoic: Implications for Vital Effects and Biomineralization through Time. Earth and Planetary Science Letters 444, 205-214. doi: 10.1016/j.epsl.2016.03.012

Gothmann, A. M., Stolarski, J., Adkins, J. F., Schoene, B., Dennis, K. J., Schrag, D. P., et al. (2015). Fossil Corals as an Archive of Secular Variations in SW Chemistry since the Mesozoic. Geochimica et Cosmochimica Acta 160, 188-208. doi: 10.1016/j.gca.2015.03.018

Hardie, L. A. (1996). Secular Variation in SW Chemistry: An Explanation for the Coupled Secular Variation in the Mineralogies of Marine Limestones and Potash Evaporites over the Past 600 m.Y. Geology 24, 279-283. doi: 10.1130/ 0091-76131996024<0279:SVISCA<2.3.CO

Hathorne, E. C., Gagnon, A., Felis, T., Adkins, J., Asami, R., Boer, W., et al. (2013a). Interlaboratory study for coral $\mathrm{Sr} / \mathrm{Ca}$ and other element/Ca ratio measurements. Geochemistry, Geophysics. Geosystems 14, 3730-3750. doi: 10. 1002/ggge.20230

Hathorne, E. C., Thomas, F., Atsushi, S., Hodaka, K., and Cabioch, G. (2013b). Lithium in the Aragonite Skeletons of Massive Porites Corals: A New Tool to Reconstruct Tropical Sea Surface Temperatures. Paleoceanography 28, 143-152. doi: 10.1029/2012PA002311

Hauzer, H., Evans, D., Müller, W., Rosenthal, Y., and Erez, J. (2018). Calibration of Na Partitioning in the Calcitic Foraminifer Operculina Ammonoides under Variable Ca Concentration: Toward Reconstructing Past SW Composition. Earth and Planetary Science Letters 497, 80-91. doi: 10.1016/j.epsl.2018.06.004

Horita, J., Zimmermann, H., and Holland, H. D. (2002). Chemical Evolution of SW during the Phanerozoic. Geochimica et Cosmochimica Acta 66, 3733-3756. doi: 10.1016/S0016-7037(01)00884-5

Houedec, S. L., Erez, J., and Rosenthal, Y. (2021). Testing the influence of changing seawater Ca concentration on Elements/Ca ratios in planktic foraminifera: A culture experiment. Geochemistry, Geophysics, Geosystems 22, e2020GC009496. doi: 10.1029/2020GC009496

Howard, L. S., and Brown, B. E. (1984). Heavy metals and reef corals. Oceanogr. Mar. Biol. Ann. Rev. 22, 195-210.

Inoue, M., Gussone, N., Koga, Y., Iwase, A., Suzuki, A., Sakai, K., et al. (2015). Controlling Factors of Ca Isotope Fractionation in Scleractinian Corals Evaluated by Temperature, $\mathrm{PH}$ and Light Controlled Culture Experiments. Geochimica et Cosmochimica Acta 167, 80-92. doi: 10.1016/j.gca.2015.0 6.009

Kawabata, T., Takeda, Y., Hori, M., Kandori, K., and Yaji, T. (2021). Partitioning of sodium into calcium carbonates synthesized at $10-40{ }^{\circ} \mathrm{C}$ : Influence of organic ligands and temperature. Chemical Geology 559, 119904. doi: 10.1016/j. chemgeo.2020.119904

Kinsman, D. J. J. (1970). Trace cations in aragonite. Abstr. Geol. Soc. Am. 2, 596-597.

Kinsman, J. J., and Holland, H. D. (1969). The Co-Precipitation of Cations with $\mathrm{CaCO} 3$ - IV. The Co-Precipitation of Sr2+ with Aragonite between 16" and $96^{\circ}$ C. Geochimica et Cosmochimica Acta 33, 1-17. doi: 10.1016/0016-7037(69) 90089-1

Kitano, Y., Okumura, M., and Idogaki, M. (1975). Incorporation of Sodium, Chloride and Sulfate with Calcium Carbonate. Geochemical Journal 9, 75-84. doi: 10.2343 /geochemj.9.75

LaVigne, M., Grottoli, A. G., Palardy, J. E., and Sherrell, R. M. (2016). Multi-Colony Calibrations of Coral Ba/Ca with a Contemporaneous in Situ SW Barium Record. Geochimica et Cosmochimica Acta 179, 203-216. doi: 10.1016/j.gca. 2015.12.038

LaVigne, M., Hill, T. M., Spero, H. M., and Guilderson, T. P. (2011). Bamboo Coral $\mathrm{Ba} / \mathrm{Ca}$ : Calibration of a New Deep Ocean Refractory Nutrient Proxy. Earth and Planetary Science Letters 312, 506-515. doi: 10.1016/j.epsl.2011.10.013

Lea, D. W., Shen, G. T., and Boyle, E. A. (1989). Coralline barium records temporal variability in equatorial Pacific up- welling. Nature 340, 373-376.

Livingston, H. D., and Thompson, G. (1971). Trace Elements Concentration in Some Modern Corals. Limnology and Oceanography 16, 786-796.

Lough, J. M., and Barnes, D. J. (1990). Possible Relationships between Environmental Variables and Skeletal Density in a Coral Colony from the Central Great Barrier Reef. J. Exp. Mar. Biol. Ecol. 134, 221-241.

Marchitto, T. M., Bryan, S. P., Doss, W., McCulloch, M. T., and Montagna, P. (2018). A Simple Biomineralization Model to Explain Li, Mg, and $\mathrm{Sr}$ Incorporation into Aragonitic Foraminifera and Corals. Earth and Planetary Science Letters 481, 20-29. doi: 10.1016/j.epsl.2017.10.022

Marriott, C. S., Henderson, G. M., Belshaw, N. S., and Tudhope, A. L. (2004a). Temperature Dependence of d $7 \mathrm{Li}, \mathrm{d} 44 \mathrm{Ca}$ and $\mathrm{Li} / \mathrm{Ca}$ during Growth of Calcium Carbonate. Earth and Planetary Science Letters 222, 615-624. doi: 10.1016/j.epsl.2004.02.031

Marriott, C. S., Henderson, G. M., Crompton, R., Staubwasser, M., and Shaw, S. (2004b). Effect of Mineralogy, Salinity, and Temperature on Li/Ca and Li Isotope Composition of Calcium Carbonate. Chemical Geology 212, 5-15. doi: 10.1016/j.chemgeo.2004.08.002

Marshall, J. F., and McCulloch, M. T. (2002). An Assessment of the Sr/Ca Ratio in Shallow Water Hermatypic Corals as a Proxy for Sea Surface Temperature. Geochimica et Cosmochimica Acta 66, 3263-3280. doi: 10.1016/S0016-7037(02) 00926-2

McConnaughey, T. (1989). C-13 and O-18 Isotopic Disequilibrium in Biological Carbonates .1. Patterns. Geochimica et Cosmochimica Acta 53, 151-162.

McCulloch, M. T., D'Olivo, J. P., Falter, J., Holcomb, M., and Trotter, J. A. (2017). Coral calcification in a changing World: the interactive dynamics of $\mathrm{pH}$ and DIC up-regulation. Nature Communications 8, 686.

McCulloch, M. T., Fallon, S., Wyndham, T., Hendy, E., Lough, J., and Barnes, D. (2003). Coral record of increased sediment flux to the inner Great Barrier Reef since European settlement. Nature 421, 727-730.

McCulloch, M. T., Falter, J., Trotter, J., and Montagna, P. (2012). Coral resilience to ocean acidification and global warming through $\mathrm{pH}$ up- regulation. Nature Climate Change 2, 623-627.

McCulloch, M. T., Gagan, G. K., Mortimer, G. E., Chivas, A. R., and Isdale, P. J (1994). A High-Resolution $\mathrm{Sr} / \mathrm{Ca}$ and $\delta \mathrm{O}^{18}$ Coral Record from the Great Barrier Reef, Australia, and the 1982-1983 El Nino. Geochimica et Cosmochimica Acta $58,2747-2754$.

Mitsuguchi, T., and Kawakami, T. (2012). Potassium and Other Minor Elements in Porites Corals: Implications for Skeletal Geochemistry and Paleoenvironmental Reconstruction. Coral Reefs 31, 671-681. doi: 10.1007/s00338-012-0902-3

Mitsuguchi, T., Matsumoto, E., Abe, O., Uchida, T., and Isdale, P. J. (1996). Mg/Ca Thermometry in Coral Skeletons. Science 274, 961-963. doi: 10.1126/science. 274.5289.961

Mitsuguchi, T., Matsumoto, E., and Uchida, T. (2003). Mg/Ca and Sr/Ca Ratios of Porites Coral Skeleton: Evaluation of the Effect of Skeletal Growth Rate. Coral Reefs 22, 381-388. doi: 10.1007/s00338-003-0326-1

Mitsuguchi, T., Uchida, T., and Matsumoto, E. (2010). Na / Ca Variability in Coral Skeletons. Geochemical Journal 44, 261-273. 
Montagna, P., McCulloch, M., Douville, E., López Correa, M., Trotter, J., RodolfoMetalpa, R., et al. (2014). Li/Mg Systematics in Scleractinian Corals: Calibration of the Thermometer. Geochimica et Cosmochimica Acta 132, 288-310. doi: 10.1016/j.gca.2014.02.005

Ohno, Y., Iguchi, A., Shinzato, C., Inoue, M., Suzuki, A., Sakai, K., et al. (2017). An aposymbiotic primary coral polyp counteracts acidification by active $\mathrm{pH}$ regulation. Sci. Rep. 7, 40324.

Okumura, M., and Kitano, Y. (1986). Coprecipitation of Alkali Metal Ions with Calcium Carbonate. Geochimica et Cosmochimica Acta 50, 49-58. doi: 10.1016/ 0016-7037(86)90047-5

Pierrot, D., Lewis, E., and Wallace, D. (2006). MS Excel program developed for CO2 system calculations: ORNL/CDIAC-105a. Oak Ridge, TN: Carbon Dioxide Information Analysis Center, Oak Ridge National Laboratory, US Department of Energy.

Pilson, M. E. Q. (2013). An Introduction to the Chemistry of the Sea, 2 Edn. Cambridge: Cambridge university press.

Raddatz, J., Liebetrau, V., Rüggeberg, A., Hathorne, E., Krabbenhöft, A., Eisenhauer, A., et al. (2013). Stable Sr-Isotope, $\mathrm{Sr} / \mathrm{Ca}, \mathrm{Mg} / \mathrm{Ca}, \mathrm{Li} / \mathrm{Ca}$ and $\mathrm{Mg} / \mathrm{Li}$ Ratios in the Scleractinian Cold-Water Coral Lophelia Pertusa. Chemical Geology 352, 143-152. doi: 10.1016/j.chemgeo.2013.06.013

Raz-Bahat, M., Erez, J., and Rinkevich, B. (2006). In vivo light-microscopic documentation for primary calcification processes in the hermatypic coral Stylophora pistillata. Cell. Tissue Res. 325, 361-368.

Ries, J. B. (2004). Effect of Ambient $\mathrm{Mg} / \mathrm{Ca}$ Ratio on $\mathrm{Mg}$ Fractionation in Calcareous Marine Invertebrates: A Record of the Oceanic Mg/Ca Ratio over the Phanerozoic. Geology 32, 981-984. doi: 10.1130/G20851.1

Ries, J. B., Stanley, S. M., and Hardie, L. A. (2006). Scleractinian corals produce calcite, and grow more slowly, in artificial Cretaceous seawater. Geology 34, 525-528. doi: 10.1130/G22600.1

Rollion-Bard, C., and Blamart, D. (2015). Possible Controls on Li, Na, and Mg Incorporation into Aragonite Coral Skeletons. Chemical Geology 396, 98-111. doi: 10.1016/j.chemgeo.2014.12.011

Ross, C. L., DeCarlo, T. M., and McCulloch, M. T. (2019). Environmental and Physiochemical Controls on Coral Calcification along a Latitudinal Temperature Gradient in Western Australia. Global Change Biology 25, 431447. doi: $10.1111 / \mathrm{gcb} .14488$

Schneider, K., and Erez, J. (2006). The Effect of Carbonate Chemistry on Calcification and Photosynthesis in the Hermatypic Coral Acropora Eurystoma. Limnology and Oceanography 51, 1284-1293. doi: 10.4319/lo.2006.51.3.1284

Sevilgen, D. S., Venn, A. A., Hu, M. Y., Tambutté, E., De Beer, D., Planas-Bielsa, V., et al. (2019). Full in Vivo Characterization of Carbonate Chemistry at the Site of Calcification in Corals. Science Advances 5, 7447. doi: 10.1126/sciadv.aau7447

Shen, G. T., and Boyle, E. A. (1987). Lead in Corals: Reconstruction of Historical Industrial Fluxes to the Surface Ocean. Earth and Planetary Science Letters 82, 289-304. doi: 10.1016/0012-821X(87)90203-2

Shen, G. T., and Boyle, E. A. (1988). Determination of Lead, Cadmium and Other Trace Metals in Annually-Banded Corals. Chemical Geology 67, 47-62. doi: 10.1016/0009-2541(88)90005-8

Sholkovitz, E., and Shen, G. T. (1995). The Incorporation of Rare Earth Elements in Modern Coral. Geochimica et Cosmochimica Acta 59, 2749-2756. doi: 10.1016/ 0016-7037(95)00170-5

Sinclair, D. J. (2005). Non-river flood barium signals in the skeletons of corals from coastal Queensland. Australia. Earth Planet. Sci. Lett. 237, 354-369.
Sinclair, D. J. (2015). RBME Coral Temperature Reconstruction: An Evaluation, Modifications, and Recommendations. Geochimica et Cosmochimica Acta 154, 66-80. doi: 10.1016/j.gca.2015.01.006

Sinclair, D. J., Williams, B., and Risk, M. (2006). A Biological Origin for Climate Signals in Corals - Trace Element 'Vital Effects' Are Ubiquitous in Scleractinian Coral Skeletons. Geophysical Research Letters 33, 183. doi: 10. 1029/2006GL027183

Smith, S. V., Buddemeier, R. W., Redalje, R. C., and Houck, J. E. (1979). StrontiumCalcium Thermometry in Coral Skeletons. Science 204, 404-407. doi: 10.1126/ science.204.4391.404

Swart, P. K. (1979). Effect of seawater calcium concentrations on the growth and skeletal composition of a scleractinian coral - Acropora squamosa. J. Sediment. Petrol. 49, 951-954.

Swart, P. K. (1981). The Strontium, Magnesium and Sodium Composition of Recent Scleractinian Coral Skeletons as Standards for Palaeoenvironmental Analysis. Palaeogeography, Palaeoclimatology, Palaeoecology 34, 115-136. doi: 10.1016/0031-0182(81)90060-2

Tambutte, E., Tambutte, S., Segonds, N., Zoccola, D., Venn, A., Erez, J., et al. (2012). Calcein Labelling and Electrophysiology: Insights on Coral Tissue Permeability and Calcification. Proceedings of the Royal Society B: Biological Sciences 279, 19-27. doi: 10.1098/rspb.2011.0733

Tambutté, S., Holcomb, M., Ferrier-Pagès, C., Reynaud, S., Tambutté, E., Zoccola, D., et al. (2011). Coral Biomineralization: From the Gene to the Environment. Journal of Experimental Marine Biology and Ecology 408, 58-78. doi: 10.1016/j. jembe.2011.07.026

Venn, A. A., Bernardet, C., Chabenat, A., Tambutté, E., and Tambutté, S. (2020). Paracellular Transport to the Coral Calcifying Medium: Effects of Environmental Parameters. The Journal of Experimental Biology 223, 227074. doi: $10.1242 /$ jeb.227074

Venn, A., Tambutté, E., Holcomb, M., Allemand, D., and Tambutté, S. (2011). Live Tissue Imaging Shows Reef Corals Elevate PH under Their Calcifying Tissue Relative to Seawater. PLoS ONE 6:20013. doi: 10.1371/journal.pone.0020013

Yamazaki, T., Yano, M., Harii, S., and Watanabe, T. (2021). Effects of light on the $\mathrm{Ba} / \mathrm{Ca}$ ratios in coral skeletons. Chemical Geology 559, 119911. doi: 10.1016/j. chemgeo.2020.119911

Yamazato, K. (1966). Calcification in a Solitary Coral, Fungia Scutaria Lamarck in Relation to Environmental Factors. PhD Thesis. Honolulu, HI: University of Hawaii.

Yoshimura, T., Tamenori, Y., Suzuki, A., Kawahata, H., Iwasaki, N., Hasegawa, H., et al. (2017). Altervalent Substitution of Sodium for Calcium in Biogenic Calcite and Aragonite. Geochimica et Cosmochimica Acta 202, 21-38. doi: 10.1016/j.gca. 2016.12.003

Conflict of Interest: The authors declare that the research was conducted in the absence of any commercial or financial relationships that could be construed as a potential conflict of interest.

Copyright $(2021$ Ram and Erez. This is an open-access article distributed under the terms of the Creative Commons Attribution License (CC BY). The use, distribution or reproduction in other forums is permitted, provided the original author(s) and the copyright owner(s) are credited and that the original publication in this journal is cited, in accordance with accepted academic practice. No use, distribution or reproduction is permitted which does not comply with these terms. 